MASEC-SCR--81-092

DE82 013416

\section{ALTERNATIVES FOR REDUCING HOT-WATER BILLS}

\section{BEL 81-06}

\author{
Gerald E. Bennington \\ Peter C. Spewak
}

Prepared for the

Mid-American Solar Energy Center

Contract Number MA-SC-80-VA-11079

\section{BENN INGTON ENTERPRI SES, LIMITED \\ P.O. Box 866 \\ Vi enna, VA 22180}

June 1981

DISTRIRHTIOH OE THE ANMHMEHT IS HAH IMPTED

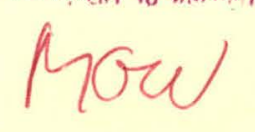




\section{DISCLAIMER}

This report was prepared as an account of work sponsored by an agency of the United States Government. Neither the United States Government nor any agency Thereof, nor any of their employees, makes any warranty, express or implied, or assumes any legal liability or responsibility for the accuracy, completeness, or usefulness of any information, apparatus, product, or process disclosed, or represents that its use would not infringe privately owned rights. Reference herein to any specific commercial product, process, or service by trade name, trademark, manufacturer, or otherwise does not necessarily constitute or imply its endorsement, recommendation, or favoring by the United States Government or any agency thereof. The views and opinions of authors expressed herein do not necessarily state or reflect those of the United States Government or any agency thereof. 


\section{DISCLAIMER}

Portions of this document may be illegible in electronic image products. Images are produced from the best available original document. 
This report was prepared under sponsorship of the Mid-American Solar Energy Complex (MASEC) and the U.S. Department of Energy. Neither MASEC, the United States or any agency thereof, nor any of their employees, makes any warranty, expressed or implied, or assumes any legal liability or responsibility for any third party's use or the results of such use of any designs, information, apparatus, product, or process disclosed in this data, or represents that its use by such third party would not infringe privately owned rights. 
$\underline{\text { Page }}$

DNTRODUCTION

A REFERENCE CASE

STAGE ONE: DOING THE EASY THINGS

A TALE OF FIVE CITIES 9

STAGE TWO: CONSIDER A BETTER WAY 11

Gas Water Heating 11

Solar Water Heating 11

Heat Pump Water Heater 17

Heat Recovery From Heat Pumps and Air Conditioners 19

COMPARISON OF STAGE II ALTERNATIVES

REFERENCES

APPENDIX A A A-1

This book was preased as an account of work sponsored by an agency of the United Stotes Covernment.

Neither tho United States Government nor any agency thereof, nor any of their emplovees, makes any

compleseness, or usetulness of any intormation, apparatus, product, or process disclosen.

represents that its use would not infringe privately owned rights, Reterence herein to any soecifie

commercial product, process, or service by trade name, trademark, manufacturer, or otherwise, does

not necessarily constitute or imply its endorsement. recommendation, or favoring by the United

States Government or any agancy thereof. The views and opinions of outhors expressed Merein do not
necesserily state or refltect those of the United States Government 


\section{LIST OF FIGURES}

Number

Page

1 Five Representative Cities in the MASEC Region

2 Representative Energy Use For Water Heating 3

3 Indirect/Antifreeze Solar Water Heater 13

4 Direct/Draindown Solar Water Heater 14

5 Heat Pump Water Heater 18

6 Typical Installation of An Air Conditioner 20

7 Water Heating Costs Stages I and II 27

Detroit, Michigan

8 Effect of Inflation on Stages I and II Costs 28

9 Electric Water Heating Cost 30

10 Solar Water Heating Costs 31

Detroit, Michigan 


\section{IST OF TABLES}

Number $\quad$ Page

I Representative Water Heater Parameters 4

II $\quad$ Stage I Water Heater Parameters 7

III Effects Of Stage I Measures $\quad 8$

IV Solar Water Heater Design Parameters 15

V Summary of Stage II Alternatives 26 


\section{INTRODUCTION}

This study of "Alternatives for Reducing Water Heating Bills" has been funded by the Mid-American Solar Energy Complex (MASEC). The objective of the study is to examine the use of conservation and solar energy to decrease residential water heating bills.

A two stage approach to reducing residential water heating bills is described. In Stage I, simple conservation measures were included to reduce the daily hot water energy consumption and the energy losses from the water tank. Once these savings are achieved, Stage II considers more costly options for further reducing the water heating bill. Four alternatives are considered in Stage II:

- Gas Water Heaters

- Solar Water Heaters (two types)

- Heat Pump Water Heaters

- Heat Recovery from a Heat Pump or Air Conditioner

To account for variations within the MASEC region, the five "representative" cities shown in Figure 1 were examined in detail. The five cities were chosen to provide good coverage of: geography; major population centers; fuel prices; climate, and state solar incentives. Hopefully, the potential for reducing water heating bills described here will encourage families to do the simple things in Stage I and request cost and technical information tailored to their individual needs from local dealers for the alternatives in Stage $\mathrm{II}$. 
Minneapolis

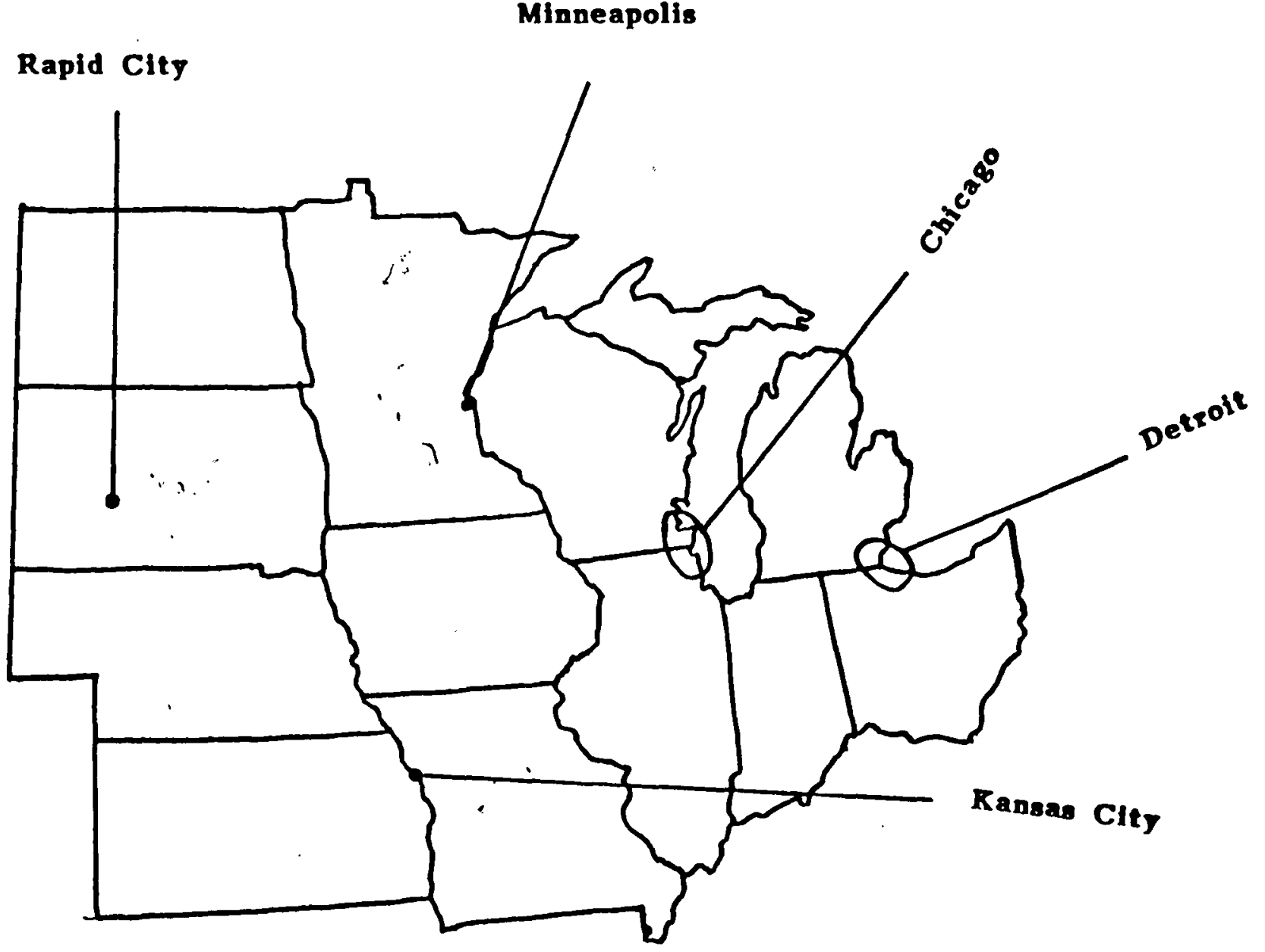

FIGURE 1

FIVE REPRESENTATTVE CITIES IN THE MASEC REGION 


\section{A REFBRENCE CASE}

To provide a basis for comparision with the alternatives presented in the later sections a representative set of reference values describing hot water heaters and hot water use are presented. The actual bot water use and water heater performance experienced by each household will likely be different but the relative merits of the alternatives should remain unchanged.

The "daily hot water energy consumption" represents the useful output of the water heater and is defined as the product of the daily hot water usage, temperature rise, and the density of water. The reference case is based on a hot water consumption of 450 gallons per week $(64.3 \mathrm{gal} /$ day $)$ and a temperature rise of $90^{\circ} \mathrm{F}$. A daily hot water energy consumption of 47,700 BTU is obtained by using the definition of one BTU as the energy needed to raise one pound of water one degree Fahrenheit and a nominal density of 8.25 pounds per gallon.

As shown in Figure 2 below, each unit of energy purchased for gas and electric water heating is divided among the useful output contained in the water actually used, the energy lost in converting from the input fuel to beated water, and the standby energy used to keep the water in the tank up to its desired temperature. The standby losses consist of the heat loss through the jacket of the tank and the flue, if one exists.

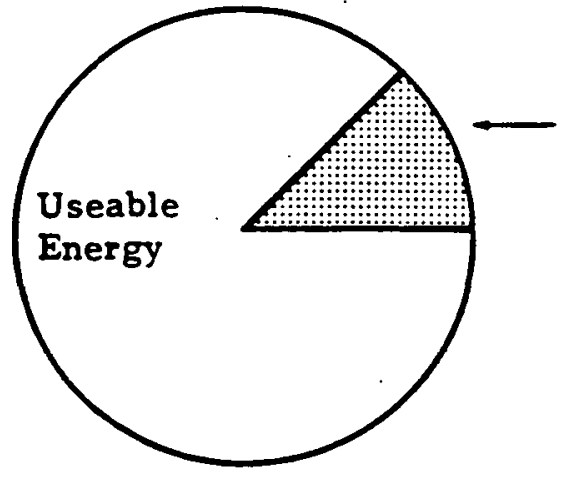

ELECTRIC RESISTANCE

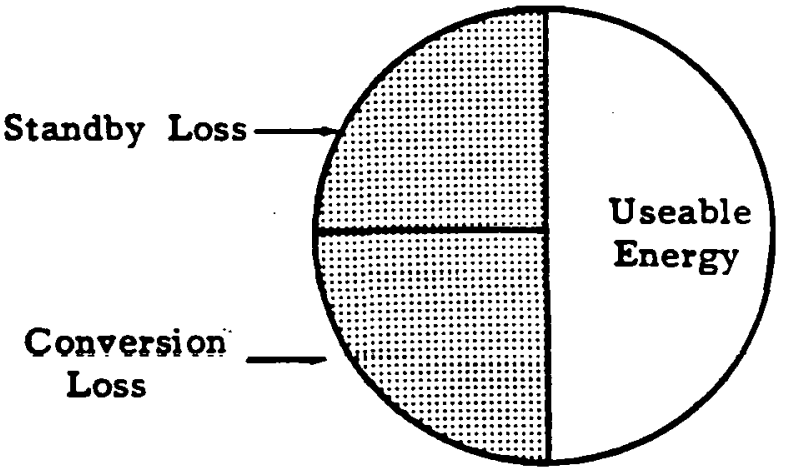

GAS-FIRED 
The water heater parameters used to estimate the reference energy use are given in Table I. The larger size of the electric resistance water heater compensates for its lower recovery rate. The conversion efficiency for the two units reflects the high end-use efficiency of converting electricity to heat. (However, electricity is a more expensive fuel, because of the energy intensive electric generating facilities used to produce the electricity.) The higher standby loss for the gas water heater reflect the industry practice of using less insulation on gas water heaters and the additional standby losses from the flue. The energy factor is a measure of the overall efficiency of the water heater and is equal to the ratio of the daily hot water energy consumption to the energy input of the water heater. (19)

TABLE I

REPRESENTATIVE WATER GEATER PARAMETERS

$\begin{array}{lccc} & \text { CONVERSION } & \text { STANDBY } & \text { ENERGY } \\ \text { SIZE } & \text { EFFECIENCY } & \text { LOSS } & \text { FACTOR } \\ \text { (GAL) } & \% & \text { (BTU/DAY) } & \%\end{array}$

ELECTRIC RESISTANCE

52

100

5,900

89

GAS-FIRED

40

76

24,800

50 


\section{STAGE ONE: DONG THE EASY TIINGS}

There have been numerous reports recommending simple ways to reduce the hot water bill. A partial list of actions include:

- cold water laundry

- reducing the hot water temperature

- increased insulation of the hot water tank

- low flow shower heads and faucets

- insulation of the hot water pipes

- reducing the water pressure

- clock timer (for electric units)

Recent articles in Consumer Report ${ }^{(15)}$ and Solar Age ${ }^{(20)}$ cite energy savings of 23 to $66 \%$ respectively through the use of steps such as these.

One of the simplest actions is to use less hot water in the laundry. Clothes washing consumes $42 \%$ of the hot water in the average household. A recent study by the Oak Ridge National Laboratory recommended that a warm wash and cold rinse combination provided the best balance between energy savings and clean clothes. ${ }^{(6)}$ The study also cited several surveys which indicated that the average wash of 5-6 pounds is being washed in a washer with a capacity of 12 pounds or more. A shift to a warm wash/çold rinse, when combined with fuller loads will save a major part of the 25 gallons of hot water used in each of the 34 washer loads run per month in the average home. The key point here is to experiment with cooler water temperatures and note any changes in color, texture or soap consumption.

A typical temperature setting for a water heater is $140-150^{\circ} \mathrm{F}$. One of the major reasons for a temperature setting this high is to provide water bot enough for an automatic dishwasher. If the hot water temperature is too low the dishwasher will not adequately remove the grease from the dishes and utensils. The dishwasher is normally 
the only use in the housebold for water this hot. The consensus in the appliance and water heating industry would favor a temperature setting of $135^{\circ} \mathrm{F}$ or higher. This ensures temperatures high enough for dishwashers and reduces the possibility of running out of hot water.

Setting the temperature back to as low as $120^{\circ} \mathrm{F}$ will provide significant energy savings by reducing the initial energy needed to heat the water as well as the standby losses from the tank while the hot water is being stored. In some cases, such as showers, the energy savings will be marginal since the user will adjust the hot/cold mixture to maintain the same comfort level. However, the standby losses will be reduced in any case. The degree of setback that is consistent with the appliances in each home will vary as will the possible effect on the family's lifestyle. A setback of $120^{\circ} \mathrm{F}$ is used for Stage I to highlight the potential for savings by this method. Check your dishwasher to see if it has a special cycle which heats the water up to the required temperature. If not, gradually reduce the hot water setting as much as you can. If you need to replace your dishwasher, look for a temperature booster feature that will allow a lower water temperature setting.

Most existing hot water heaters have inadequate tank insulation for today's energy prices. Your local hardware or lumber supplier has a do-it-yourself kit, costing approximately $\$ 20$, consisting of an insulation blanket which fits around your water heater tank. If you are more ambitious, you can use readily available materials to make a cheaper do-it-yourself job to provide even more insulation than the R-14 in the insulation kit typically provides. If you are doing it yourself, special care should be taken to assure that the facing on the insulation being used is not flammable. 
Shower use is the biggest hot water user in many families. Low flow shower heads offer an excellent potential for reducing both energy and water use. In contrast to the previous measures, this requires some adaption on the part of the family members. The low flow devices have come a long way during the lașt few years. There is a wide variety of excellent low flow devices on the market for less than $\$ 20$. Most have a shut-off button to allow full flow for washing hair and lathering up. Try it, you've only got money to save!

Other measures that will further reduce demand are to insulate the hot water pipes, reduce the water pressure (and bence the flow for all uses), and to use a clock timer for electric water heaters. Each of these options will save money eventually, but to a lesser extent the previous examples.

By implementing all three Stage I measures, the following water heater parameters are achieved:

TABLE II

STAGE I WATER HEATER PARAMETERS

$\begin{array}{lccc} & \text { CONVERSION } & \text { STANDBY } & \text { ENERGY } \\ \text { SIZE } & \text { EFFECIENCY } & \text { LOSS } & \text { FACTOR } \\ \text { (GAL) } & \% & \text { (BTU/DAY) } & \%\end{array}$

ELECTRIC RESISTANCE

GAS-FIRED
52

40
100

76
1,500

95

10,600 
A water main temperature of $50^{\circ} \mathrm{F}$, the average for the cities analyzed in the next section, was assumed along with the DOE "representative fuel prices" that were in effect April 13, 1981: electricity at $\$ 0.0564 / \mathrm{kWh}(3412 \mathrm{Btu} / \mathrm{kWh})$; natural gas at $\$ 0.426 /$ therm $(100,000 \mathrm{Btu} /$ therm); and No. 2 fuel oil at $\$ 1.24 / \mathrm{gallon}(138,600 \mathrm{Btu} / \mathrm{gal})$. These prices are used to provide the estimates of annual operating cost for the labels on hot water heaters. The analysis of the individual cities will use the prices from the current rate schedules for each city.

The annual water beating bills presented in Table III compare the reference case with the annual bills resulting from each of the first three improvements discussed.

These improvements are cheap, easy to do, and do not effect family members.

TABLE III

EFFECTS OF STAGE I MEASURES

STAGE I MEASURES INCLUDED: 'Reduce water use to 55.7 GPD $120^{\circ}$ temperature setting

Add tank insulation

DAILY HOT WATER ENERGY CONSUMPTION (BTU/DAY)

ENERGY PURCHASED (BTU/DAY) Electric Resistance Gas

ANNUAL WATER HEATING BILL Electric Resistance Gas

STAGE I MEASURES

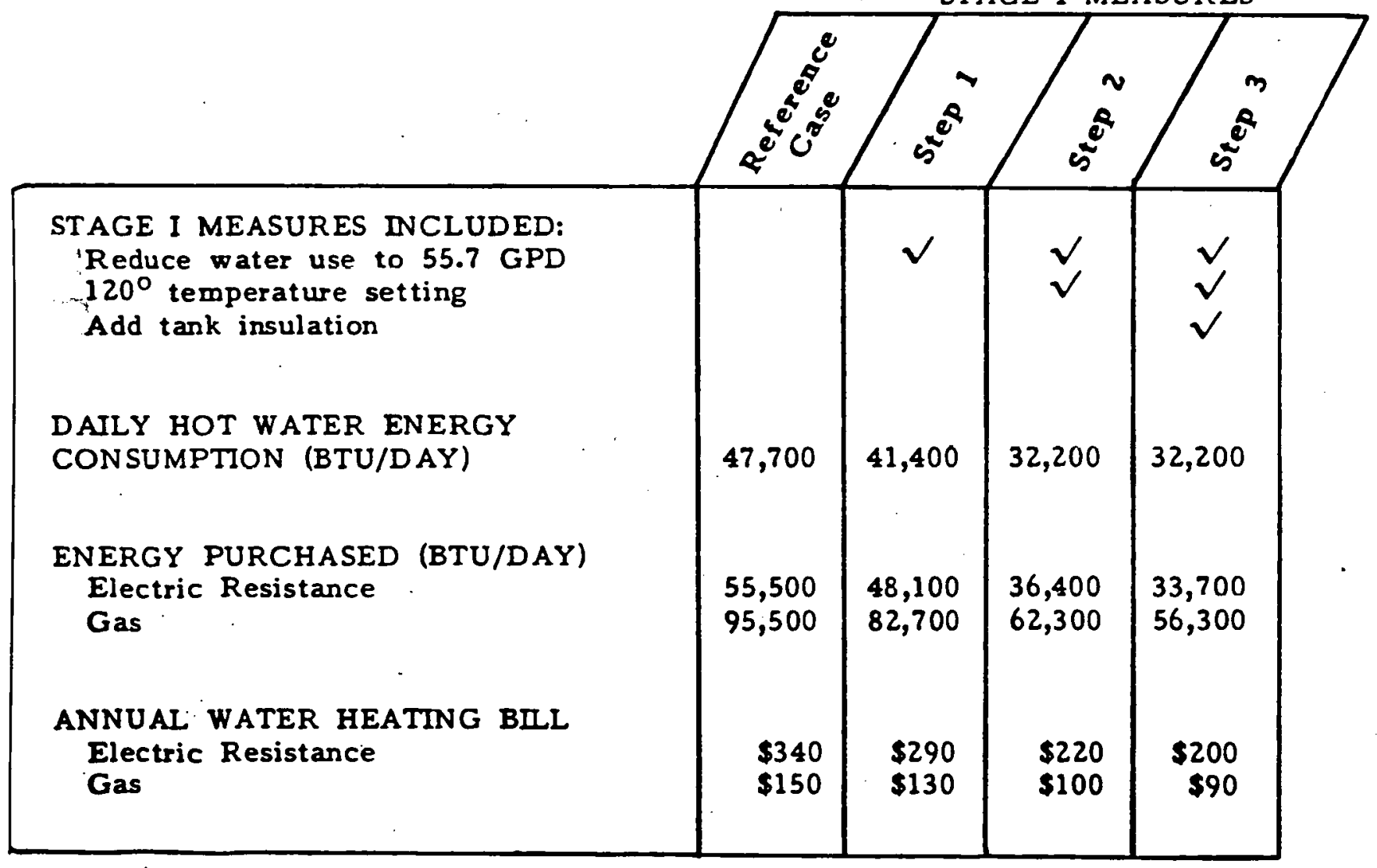




\section{A tale of Five CITES}

To provide a rough indication of how these Stage I results will vary in the Mid-American region, five representative cities were selected:

- Chicago, mlinois

- Detroit, Michigan

- Kansas City, Missouri

- Minneapolis, Minnesota

- Rapid City, South Dakota

For each city, electric and gas prices were obtained from the SOLCOST data base as of May $1980^{(16)}$ and used with estimates of the average groundwater temperatures to estimate 1981 water heating bills for each of the cities. The Stage I reductions are impressive, although they vary by city and will depend on the actual measures taken by each family. The truly amazing thing is that many people are still wasting $\$ 50-\$ 100$ per year through inaction.

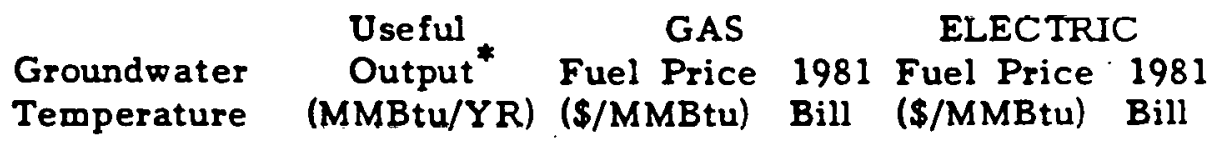

$\begin{array}{lllllll}\text { Chicago } & 50 & 11.7 & 3.40 & 70 & 19.20 & 237 \\ \text { Detroit } & 50 & 11.7 & 4.10 & 84 & 17.70 & 218 \\ \text { Kansas City } & 57 & 10.6 & 3.00 & 56 & 16.20 & 180 \\ \text { Minneapolis } & 42 & 13.1 & 3.30 & 76 & 14.80 & 204 \\ \text { Rapid City } & 47 & 12.2 & 3.00 & 64 & 13.00 & 168\end{array}$

* Useful output per year is calculated from the daily hot water energy consumption with a temperature set of $120^{\circ} \mathrm{F}$ and $55.7 \mathrm{gal} /$ day usage. Stage I water heater parameters are assumed in estimating 1981 water heating bills. 


\section{THIS PAGE WAS INTENTIONALLY LEFT BLANK}




\section{STAGE TWO: CONSTER A BETTER WAY}

For the current family with a gas water beater, Stage I will get them very close to the point where further improvements are no longer urgent. However, the owner of an electric water heater has several alternatives which need careful consideration. The following four alternatives will be analyzed:

- Convert to a gas-fired water heater

- Use solar energy

- Add a heat pump water heater

- Use heat recovery from a central air conditioner or heat pump

\section{Gas Water Heating}

Although gas hook-ups are not available everywhere, gas is the predominate water heating fuel in many parts of the country. However, many existing homes with gas hook-ups have an electric water heater. This situation has resulted from builders' preferences for lower equipment cost and ease of installation.

Many of the newer gas models are available with increased insulation and other energy saving features. An estimated installed cost of $\$ 500$ is used for a 40 gallon gas-fired water heater having $R-20$ insulation. This cost consists of roughly $\$ 300$ for the water heater and the remainder for the installation. The actual installation cost is dependent on the ease of venting the unit and hooking up the gas.

\section{Solar Water Heating}

Two solar water heating designs are used:

- Direct/draindown

- Indirect/antifreeze 
Figures 3 and 4 provide a schematic of the two system designs and the design parameters are summarized in Table IV. The direct/draindown system heats plain water "directly" in the collectors which then flows to the storage tank for use. To protect againt freezing, the water in the collectors are "drained down" by gravity flow. when the collector pump is not being used.

The indirect/antifreeze system design uses a closed loop for the collector fluid which typically contains a non-freezing fluid and corrosion inhibitors. The domestic water is heated indirectly with a heat exchanger connected to the collector loop.

The direct/draindown system is typically simpler and cheaper than an indirect/antifreeze design. However, the use of tap water in areas with hard or acidic water supply can seriously damage the collectors. The indirect systems provide a straightforward method of freeze protection and a stable operating environment for the collectors, but require a more complicated and costly design.

Both designs use an auxiliary storage tank in addition to an existing water heater. Although this increases the standby losses it is a very common design used to "retrofit" existing applications. For new or replacement applications a single tank design, with lower standby losses, should be strongly considered. The information in "Hot Water From The Sun," available from the Department of Housing and Urban Development, provide many helpful suggestions on selecting a local dealer and in understanding some of the finer points in selecting a system. (11) 


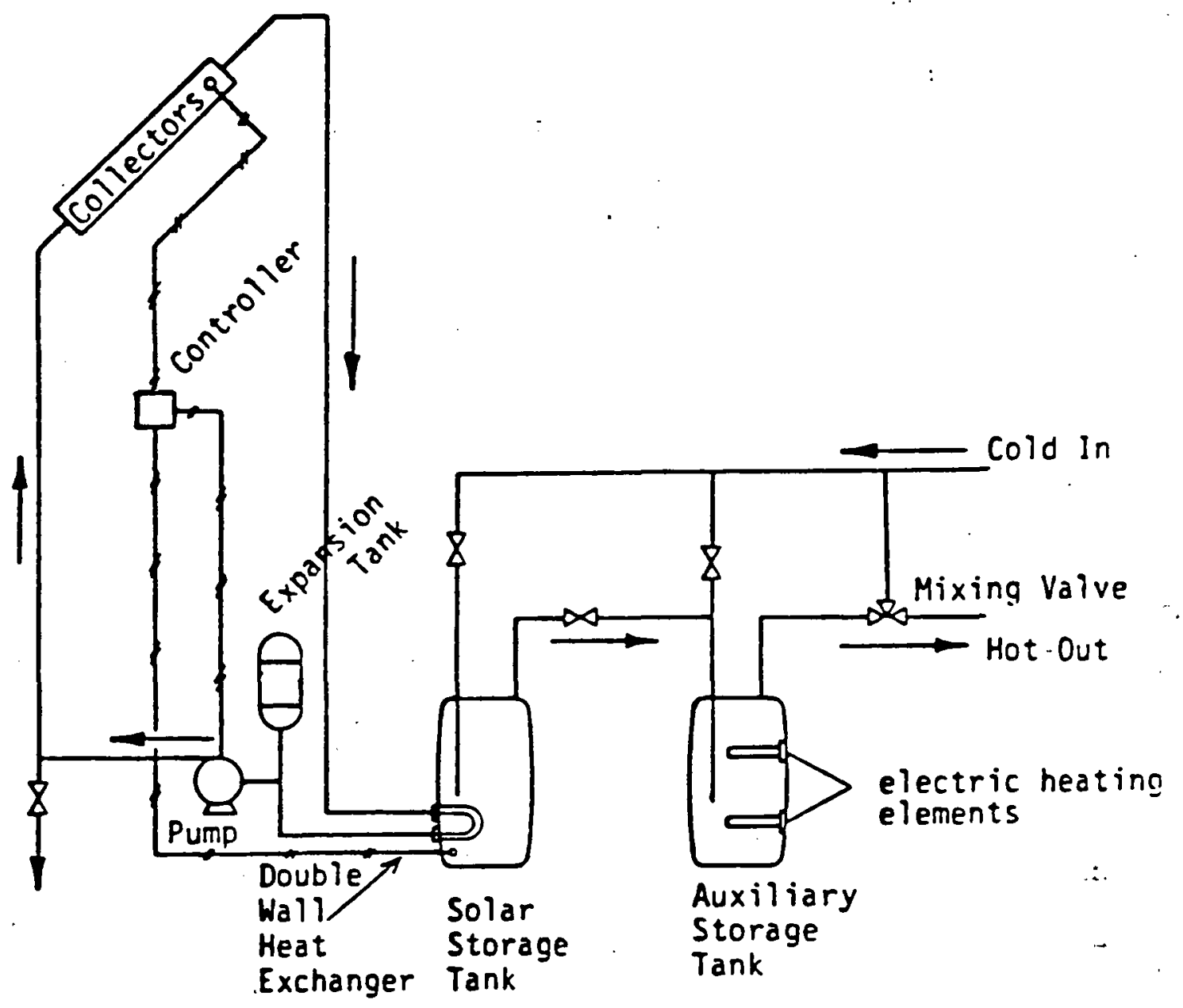

FIGURE 3

INDIRECT/ANTIFREEZE SOLAR WATER HEATER

SOURCE: SAI, Reference 4. 


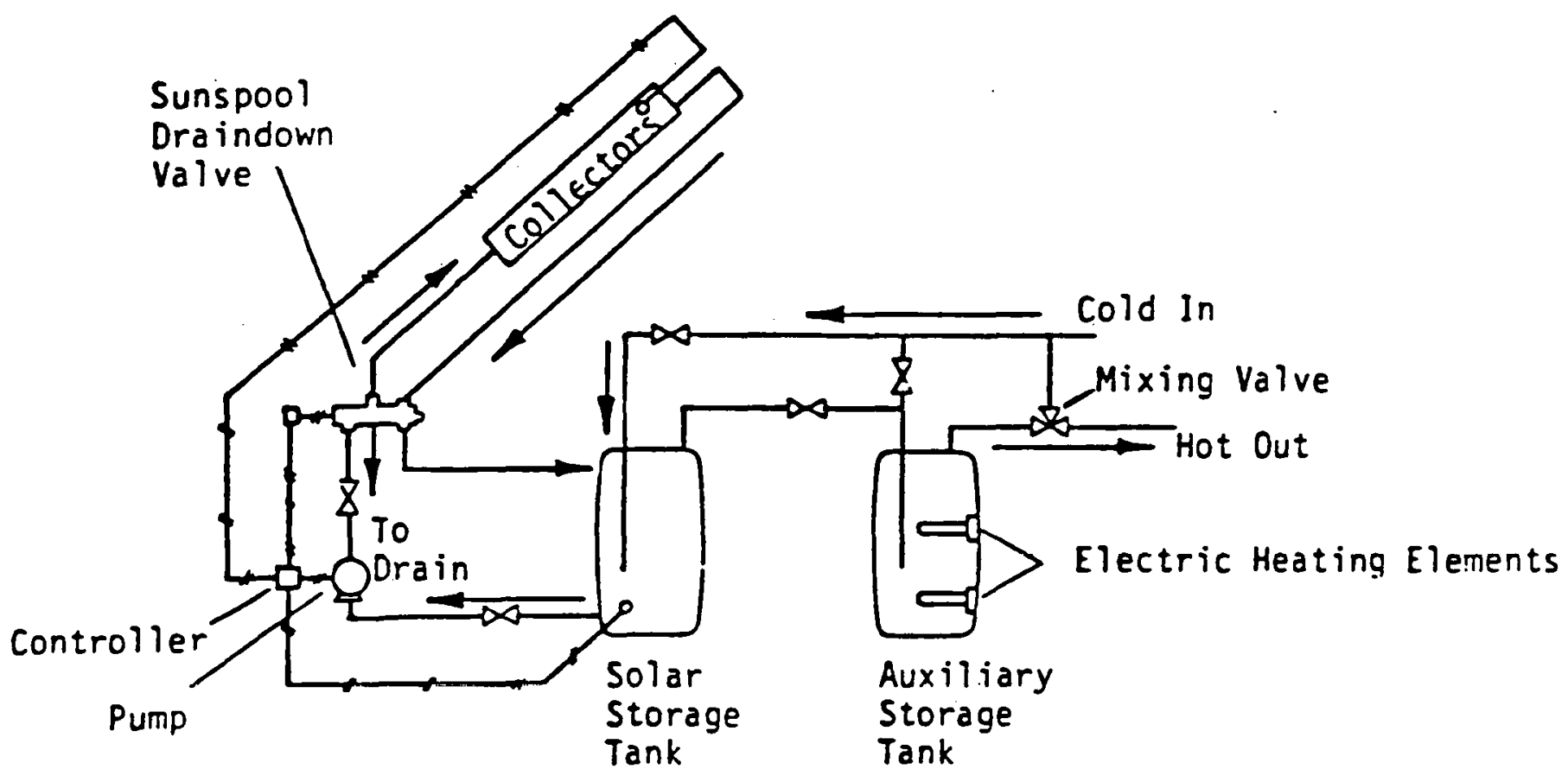

FIGURE 4

DIRECT/DRAINDOWN SOLAR WATER BEATER

SOURCE: SAI, Reference 4. 
SOLAR WATER HEATER DESIGN PARAMETERS

$\begin{array}{cc}\text { Direct } & \text { Indirect } \\ \text { Draindown } & \text { Antifreeze }\end{array}$

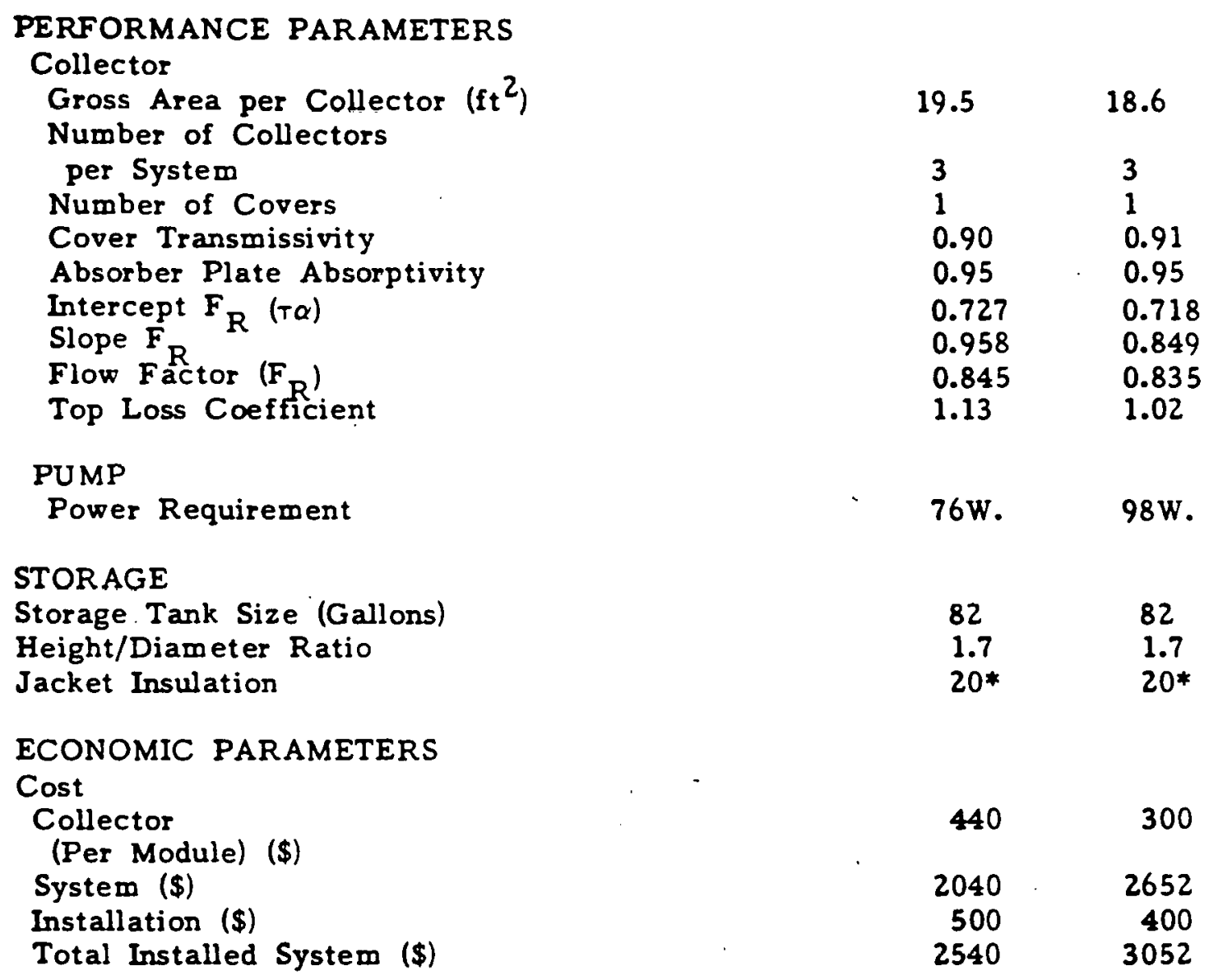

*The tank insulation has been upgraded to R-20 from the original design in Reference 3.

SOURCE: SAI, Reference 3 
- The federal and state tax credits have a dramatic effect on the net cost of purchasing a solar water heater. The current federal tax credit provides a credit of $40 \%$ of the first $\$ 10,000$ spent on a solar water heater. The federal tax credit is scheduled to end after 1985. In addition to the federal credits, many states provide additional tax subsidies for solar purchases. The current state tax credits for the five cities are given below:

\section{STATE TAX CREDITS CURRENTLY AVAHABLE(12)}

Chicago, II

Detroit, MI

Kansas City, MO

Minneapolis, MN

Rapid City, SD

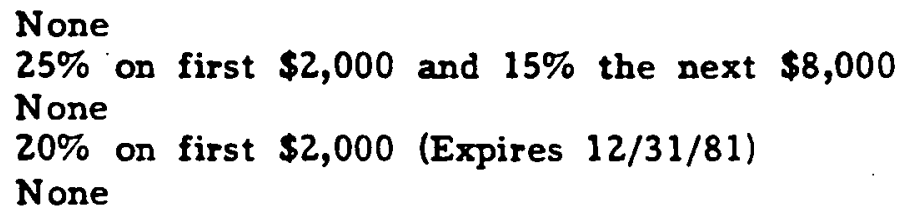

The energy savings and annual costs were estimated using the FCHART (4.0) solar design program for each of the five cities. ${ }^{(8)}$ Although field test data is available for solar water heaters, the variety and rapid rate of product improvement make it very difficult to obtain performance data directly applicable to new locations and designs. $(1,2)$ FCHART is a widely used and tested solar design program developed by the University of $W$ isconsin which provides a flexible means of estimating cost and performance for a wide variety of solar designs in over 200 locations in the United States. The detailed list of assumptions and the computer analyses are presented in Appendix A.

An economic analysis of each case was included in the FCHART output to assess the ten-year trends in increasing fuel costs and the effects of financing the purchase. A $10 \%$ inflation rate was assumed with an additional real increase of $3 \%$ per year in electric prices and $4.5 \%$ per year in gas prices. The fuel price increases are based on the American Gas Association's TERA model and incorporate the enactment of the Natural Gas Policy Act of 1978 which provides for phased new gas deregulation by 
1985. (18) These estimates for gas price escalation will probably be somewhat conservative if deregulation is accelerated, however, they provide a reasonable projection at this time. The economic analysis assumes financing of the total price of the solar system with $10 \%$ down payment and a 36-month loan at an interest rate of $18 \%$ per annum. The federal and state income tax credits appear as a tax saving.

\section{Heat Pump Water Heater}

Although heat pumps are widely used for space heating, the heat pump water heater is a relatively new product. There are currently at least five companies marketing heat pumps:

- Energy Utilization Systems, Pittsburgh, PA

- E-TECH, Atlanta, GA

- Fedders, Edison, NJ

- Northrup, Incorporated, Hutchins, TX

- The Oregon Water Heater Company, Progress, OR

Figure 5 contains a basic schematic for a heat pump water heater. The water is gradually heated by recirculating the cooler water from the bottom water heater tank through the heat exchanger in the heat pump and returning the warmer water to the top of the tank. Since the heat pump is primarily moving heat, rather than creating it, this method of water heating offers significant savings over a conventional electric water heater when installed in an unheated area. Depending on the air temperature, humidity and incoming water temperature, the coefficient of the performance (COP) is claimed to range from 1.85 to $3.17 \cdot(9,17,21)$ The design by Energy Utilization Systems, Incorporated (EUS) integrates the heat pump unit on the top of the storage tank. This system is available in three sizes $(50,66$ and 82 gallons) and has a retail price of approximately $\$ 1,100 .^{(17)}$ The E-TECH, Fedders, and Oregon Water Heater are designed as additions to a conventional electric water heater. The system is typically attached 


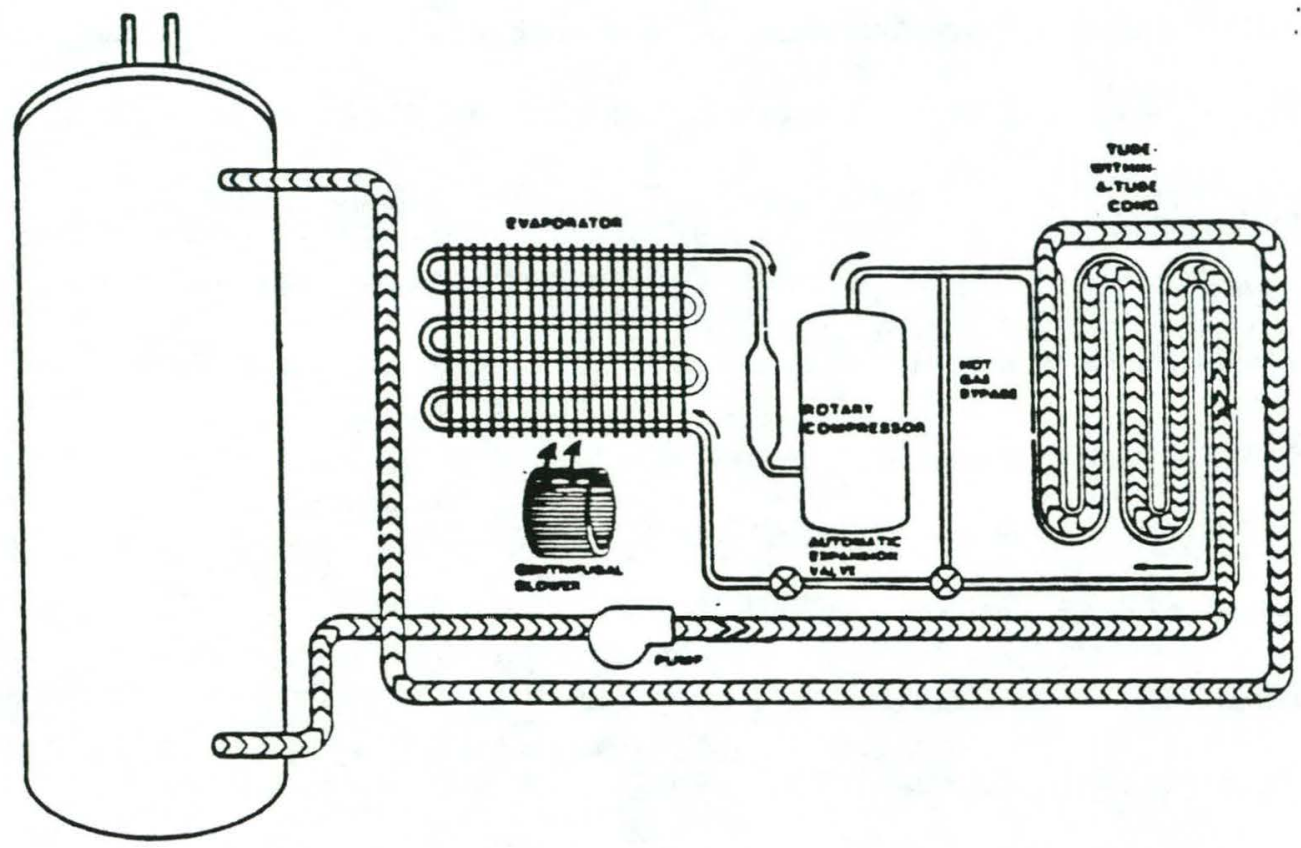

FIGURE 5

HEAT PUMP WATER HEATER

SOURCE: Fedders Corporation, Reference 9. 
by replacing the pressure/temperature valve and drain faucet with new fittings. These systems can be expected to retail for approximately $\$ 800$ (without a new tank). $(9,21$ )

Much of the interest in heat pump water heating has been spurred by a Department of Energy program to develop and field test the units. $(10,13)$ The Department of Energy sponsored a demonstration program in 1979 with 20 utilities to install and monitor heat pump water heaters in 100 homes. (5) More recently, EUS reports that is has had seventy-five utilities participate in a field demonstration of 225 units, with some demonstrations as long as 18 months.

Data from the first year of a 2-year field test being conducted by the Tennessee Valley Authority (TVA) showed energy savings of $46 \%$ for the EUS TEMCOR system and $57 \%$ for the E-TECH systems. ${ }^{(10)}$ The TVA experience has been that other than minor design problems that the manufacturers are addressing, both designs were reliable.

Field test data provided by EUS reports average energy savings of $50-57 \%$. The five examples cited for the mid-west also had the same range of savings.

A heat pump water heater costing $\$ 820$ (includes $\$ 20$ tank insulation kit) with an annual COP of 2.3 will be used for estimating the 1981 water heating bills in Stage II. It should be noted that the design goals of the DOE program are to eventually obtain an average COP approaching 3.0 for systems in residential use.

\section{Heat Recovery From Heat Pumps and Air Conditioners}

A typical heat recovery unit for use with a heat pump or air conditioner is shown in Figure 6. A small pump circulates the water from the storage tank through a heat exchanger where it is heated by the heat rejected by the compressor. The circulating pump is normally activated wherever the compressor is operating. The flow is controlled to avoid imposing off-design operating conditions on the air conditioner or heat pump. 


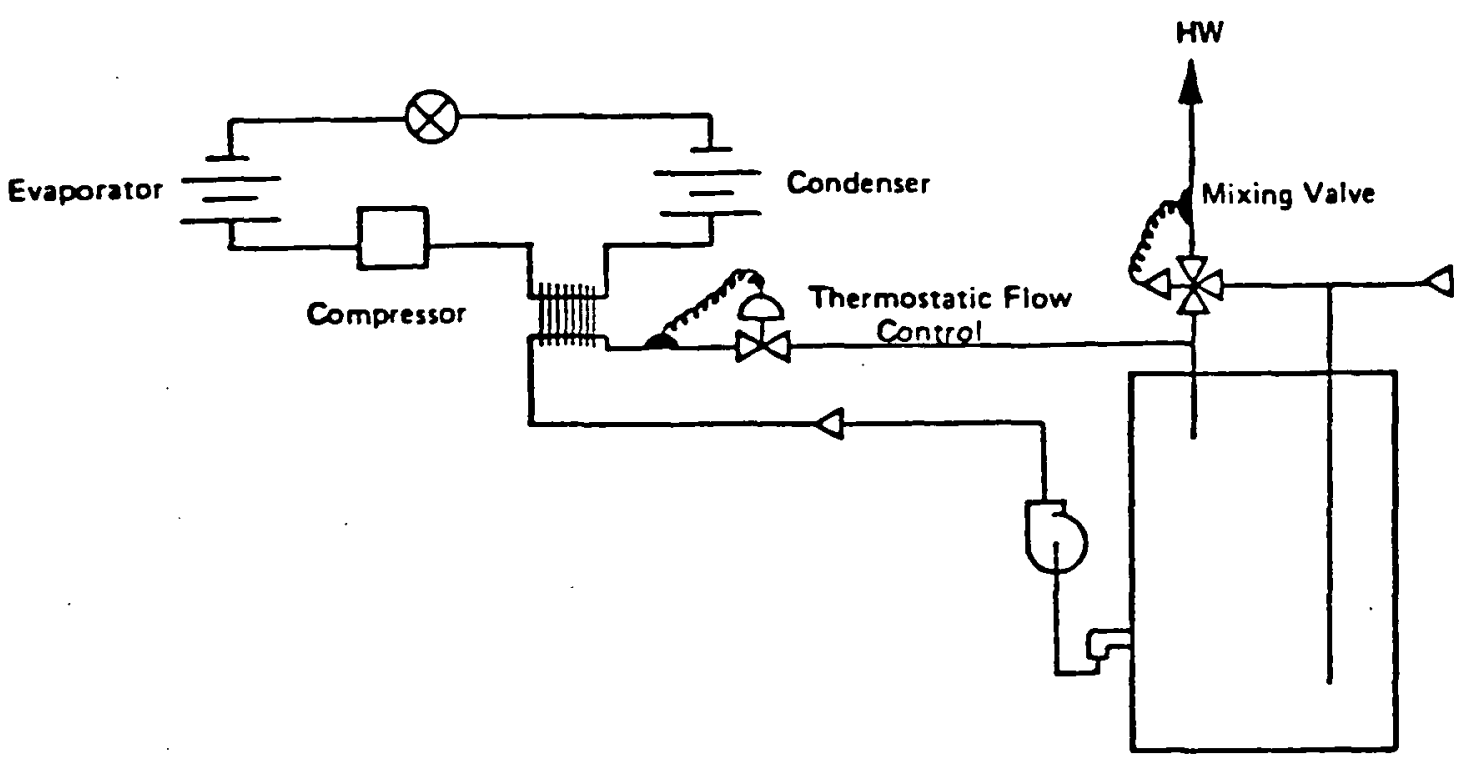

FIGURE 6

TYPICAL INSTALLATION OF AN AIR CONDITIONER (OR HEAT PUMP) WATER HEATING RECOVERY UNIT

SOURCE: EPRI, Reference 4. 
A recent study by the Electric Power Research Institute (EPRI) identified ten manufacturers of heat recovery units. (4) The EPRI study also provided a set of approximate estimates of the maximum potential savings for 13 cities.. These savings estimates are based on energy use (excluding standby losses) of $16 \mathrm{MMBtu} / \mathrm{yr}(4,685$ kWh) and assume that the recovered heat can always be used for water heating. With the Stage I energy use of roughly $12 \mathrm{MMBtu} / \mathrm{yr}$ it is questionable whether all of the heat recovered could be used. Comments provided by one reviewer indicated that realistic estimates of the operating periods for heat recovery would be roughly half of the maximum potential assumed in the EPRI study. The estimates of maximum potential savings for the cities in the MASEC region, based upon the EPRI study, are given below:

\section{MAXIMUM POTENTIAL SAVINGS (kWh/Year)}

\section{With $21 / 2$ ton $A C$ With $21 / 2$ Heat Pump}

$\begin{array}{lrr}\text { Chicago } & 1257 & 2429 \\ \text { Bismark } & 960 & 2130 \\ \text { Omaha } & 1589 & 2576\end{array}$

SOURCE: EPRI, Reference 4

There is little field test data available for beat recovery units in residential applications. However, the Arizona Public Service and Alabama Power Company have tests underway. 
The U.S. Department of Housing and Urban Development (HUD) built an "Energy Efficient Residence" and a "Conventional Comparison House" to collect research data on energy conservation techniques. (7) The conservation measures to reduce the water heating bill were:

Heavily insulated water heater

Temperature setting of $120^{\circ} \mathrm{F}$

Front loading clothes washer

Energy saving dishwasher

Low flow devices in the bathroom and kitchen

Insulated piping

Heat recovery unit on the heat pump

These measures closely parallel the Stage I recommendations plus a heat recovery unit. When combined with the conservation measures for heating, cooling and appliances, the total energy use for the year beginning February 1, 1978 showed a $54 \%$ and $32 \%$ reduction for the heating and cooling seasons respectively. The savings for the hot water are shown below:

\begin{tabular}{|c|c|c|c|}
\hline \multicolumn{2}{|c|}{$\begin{array}{l}\text { ENERGY SAVINGS } \\
\text { (kWh) } \\
\text { Heating } \\
\text { Season } \\
\end{array}$} & \multicolumn{2}{|c|}{$\begin{array}{l}\text { Cooling } \\
\text { Season }\end{array}$} \\
\hline 2396 & $(47 \%)^{*}$ & 1209 & $(55 \%)^{*}$ \\
\hline-54 & $(-60 \%)$ & -38 & $(-64 \%)$ \\
\hline 39 & $(51 \%)$ & 18 & $(45 \%)$ \\
\hline 2381 & $(45 \%)$ & 1189 & $(52 \%)$ \\
\hline
\end{tabular}

TOTAL

Hot Water Heating

Dishwasher

Clothes Washer

$2381 \quad(45 \%) \quad 1189$

$(52 \%)$

* The percentage savings are measured relative to the Conventional Comparison House. The total is not the sum of the individual elements.

Source: HUD Reference 7. 
Note that the savings attributable to the water heater are partially offset by the heater in the dishwasher. The savings cited for the clothes washer does not include the effect of change in hot water temperature or use. Unfortunately the summary data does not dissagregate the savings attributed to the heat recovery unit.

A detailed analysis well beyond the scope of this study would be needed to provide an estimate for heat recovery units comparible to the other alternatives. Due to this lack of data, a quantitative comparison will not be attempted.

However, the HUD research is an encouraging example for the use of heat recovery and conservation to reduce water heating costs. Interested consumers should consult local dealers for specific cost and technical information. 


\section{THIS PAGE WAS INTENTIONALLY LEFT BLANK}




\section{COMPARISON OF STAGE I ALTERNATIVES}

Table V summarizes 1981 water heating bills and net investment for a conventional electric water heater with the Stage I measures and the gas, solar, and heat pump water heaters from Stage II.

If the primary consideration is to minimize the fuel bill and isolate the cost of water heating from further price increases, then gas and solar can reduce the 1981 bill to less than $\$ 50$ in two of the cities.

The use of gas, solar or heat pumps are all likely to result in lower fuel bills for the next 5 years based on the assumptions used for the economic analysis. Figure 7 compares the estimates of the fuel bills for Detroit, Michigan. The choice among these alternatives depends on your estimates of the relative rates of increase on the prices of gas and electricity, and the cost, performance, and reliability of each water heater type.

A word of caution is in order at this point. The events of the past several years have been replete with unfulfilled forecasts. Changes in energy prices have seldom been as gradual or predictable as those used in the economic models. For example, the assumption of an annual price increase of $14.5 \% /$ year for natural gas is based on a gradual deregulation by 1985 . The exact nature of the change in residential price increases will vary widely based on state regulation, long-term contracts by gas utilities, and many other factors. Figure 8 illustrates the impact of a $5 \%$ variation in the annual rate of the price of electricity and gas for Detroit, Michigan. The savings of Stage II remains below the 1981 estimate for Stage I until past 1986 in the most pessimistic case shown.

The combination of federal and state tax incentives make solar water heating a very appealing alternative in several states. The credits in Michigan and Minnesota when combined with the federal credits reduce the installed cost of $\$ 2540-\$ 3050$ to as 
TABLE V

SUMMARY OF STAGE II ALTERNATIVES

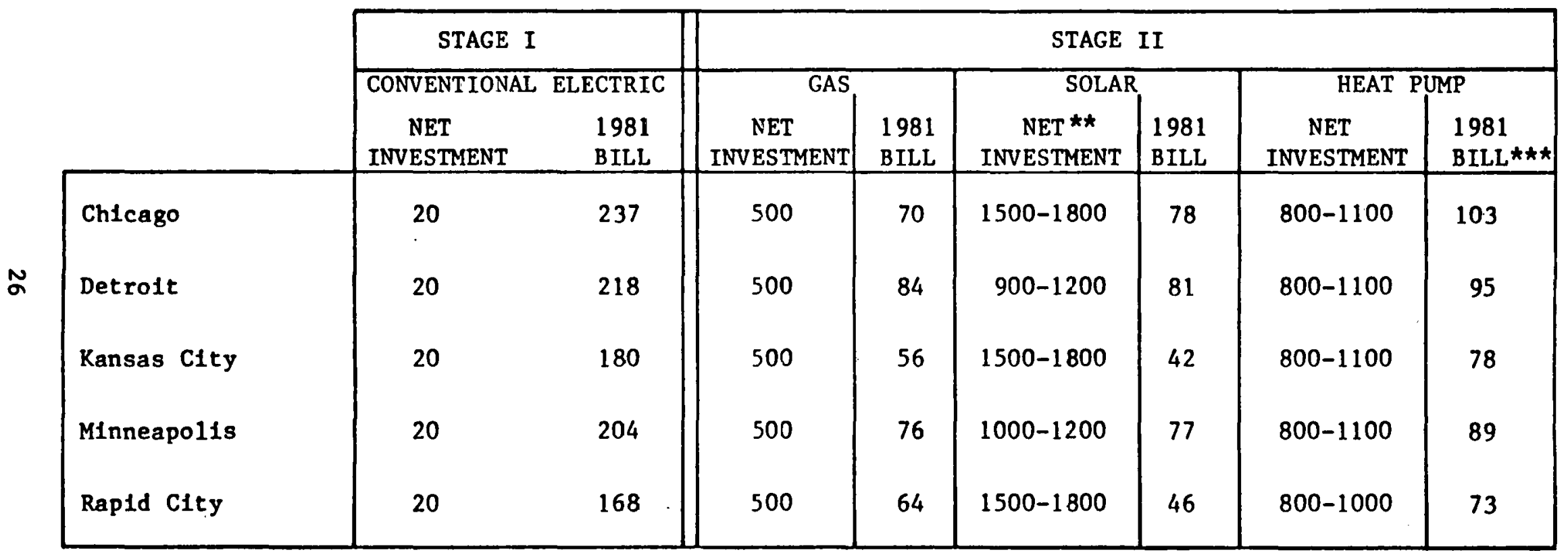

*These estimates are for general comparison. Consult your local dealers for spectfic estimates tallored to your Individual case.

**The net investment for the solar water heaters incorporates the reduced cost due to federal and state tax incentives. The $1981 \mathrm{~B} 111$ is the average of the two systems evaluated for each city.

$\star \star \star$ Based on an annual average COP of 2.3 . 


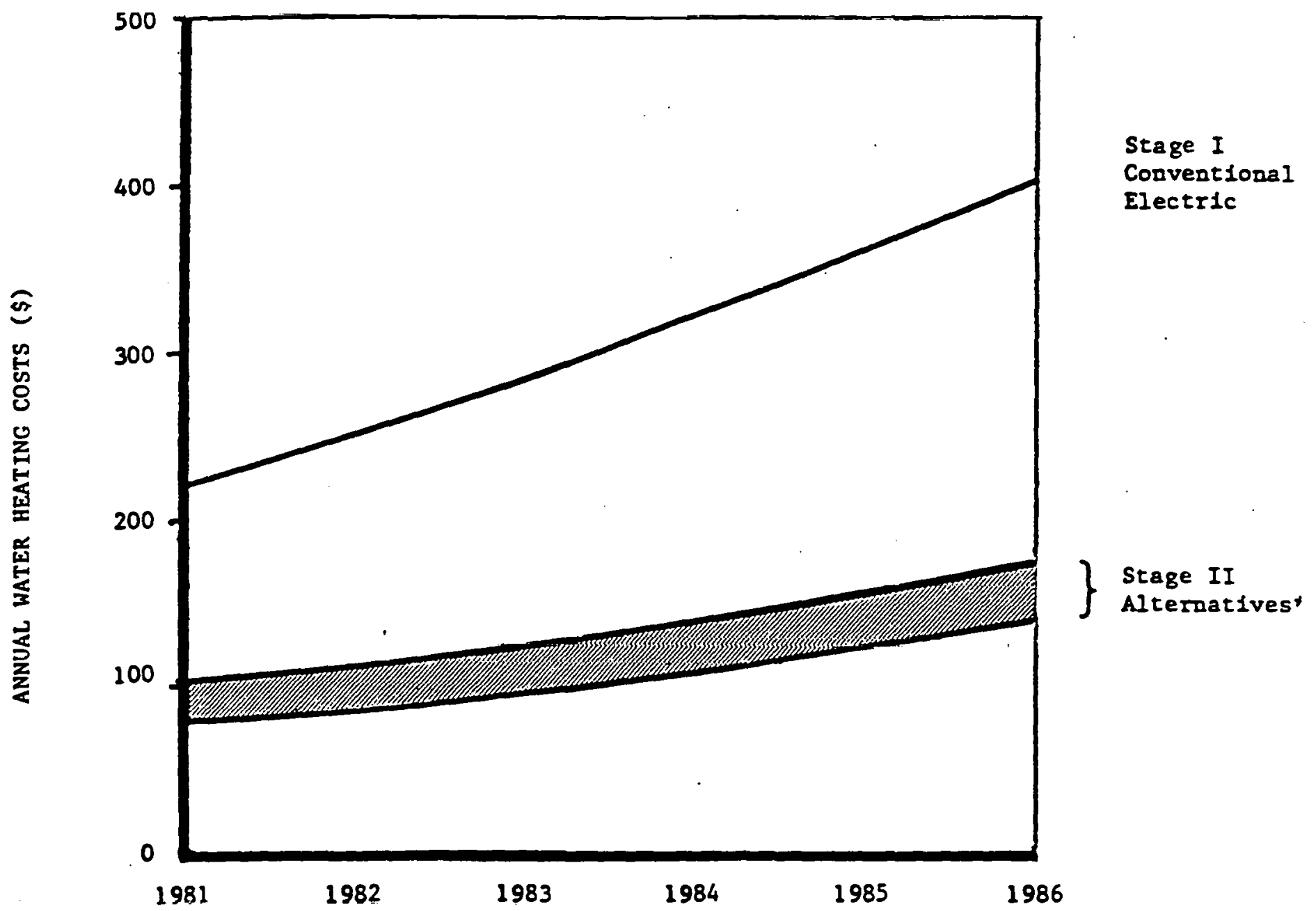

FIGURE 7

WATER heATING COSTS STAGES I AND II DETROIT, MICEIGAN

*Gas, solar, heat pump. 


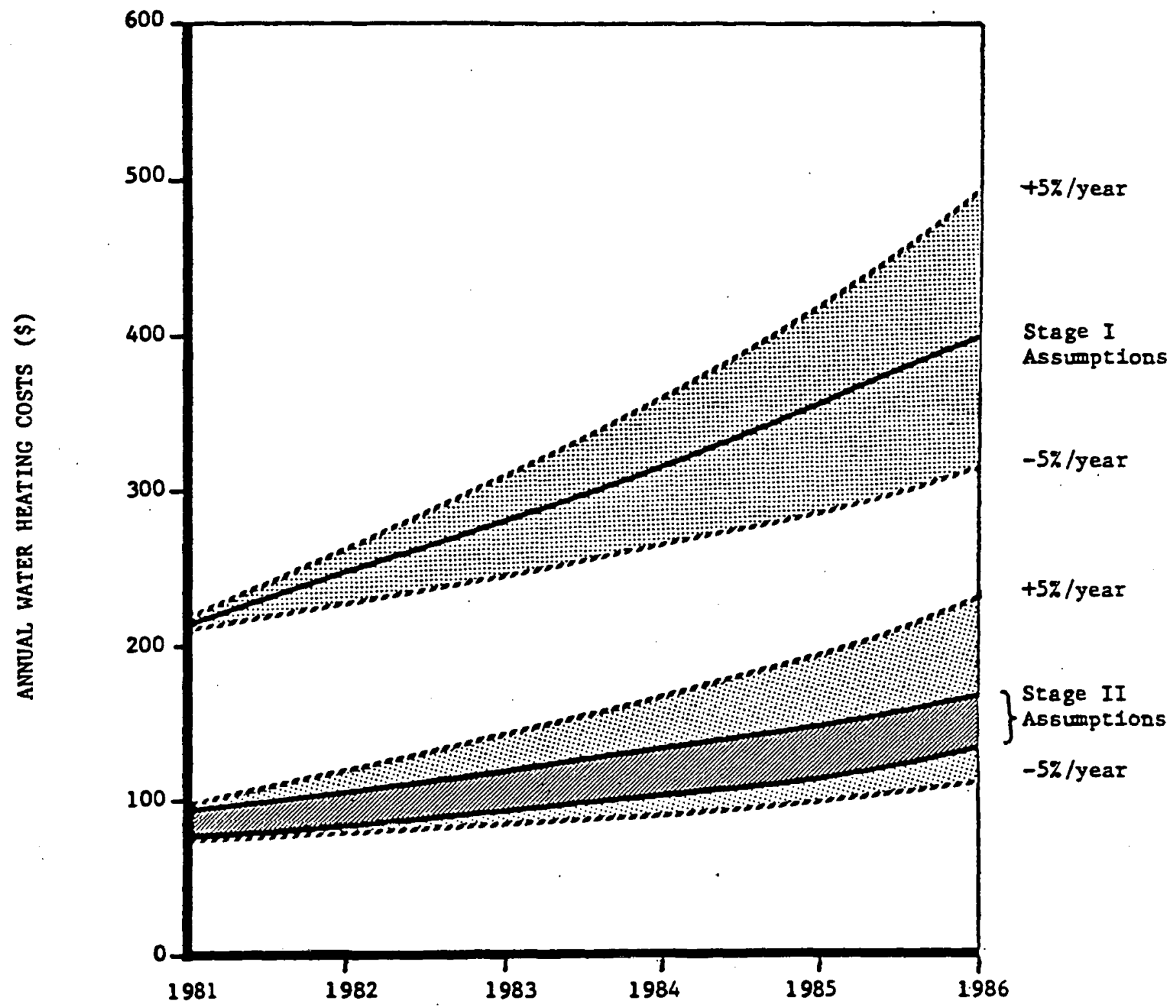

FIGURE 8

EFFECT OF INFLATION ON STAGES I AND II COSTS DETROIT, MICEIGAN 
low as $\$ 900$. This may be one of the few cases where the homeowner can actually get something from the government!

Once the tax refund is received the homeowner actually has a cash surplus over most of the first two years. A possible alternative to accelerate the effect of the federal refund would be to estimate the 1981 federal income tax and to reduce the amount of withholding. In some cases this could result in an additional \$60-100 per month in disposable income. Figures 9 and 10 compare the net annual cost for conventional electric and solar water heaters in Detroit, Michigan. 


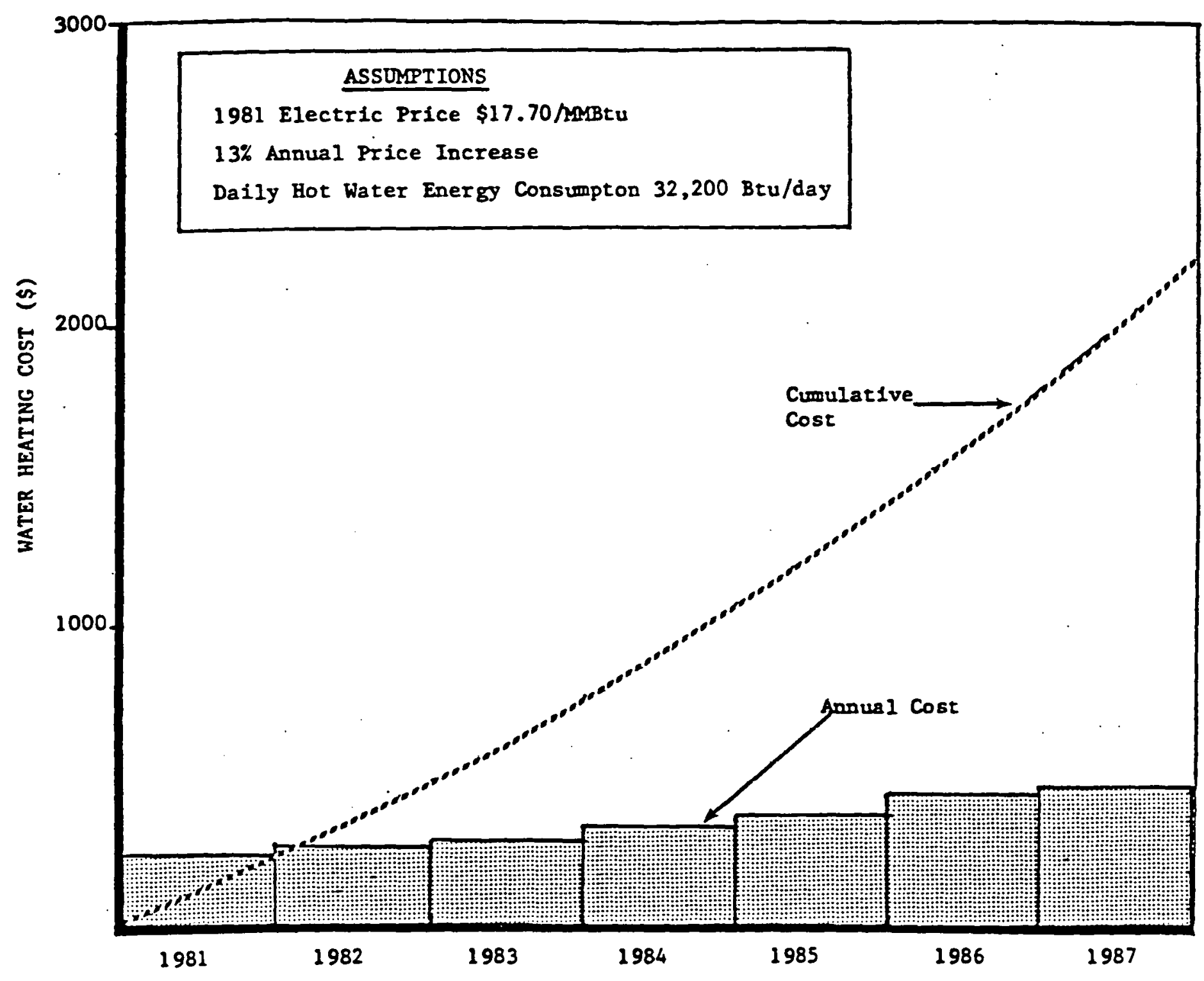

FIGURE 9

ELECTRIC WATER HEATING COST DETROIT, MICEIGAN 


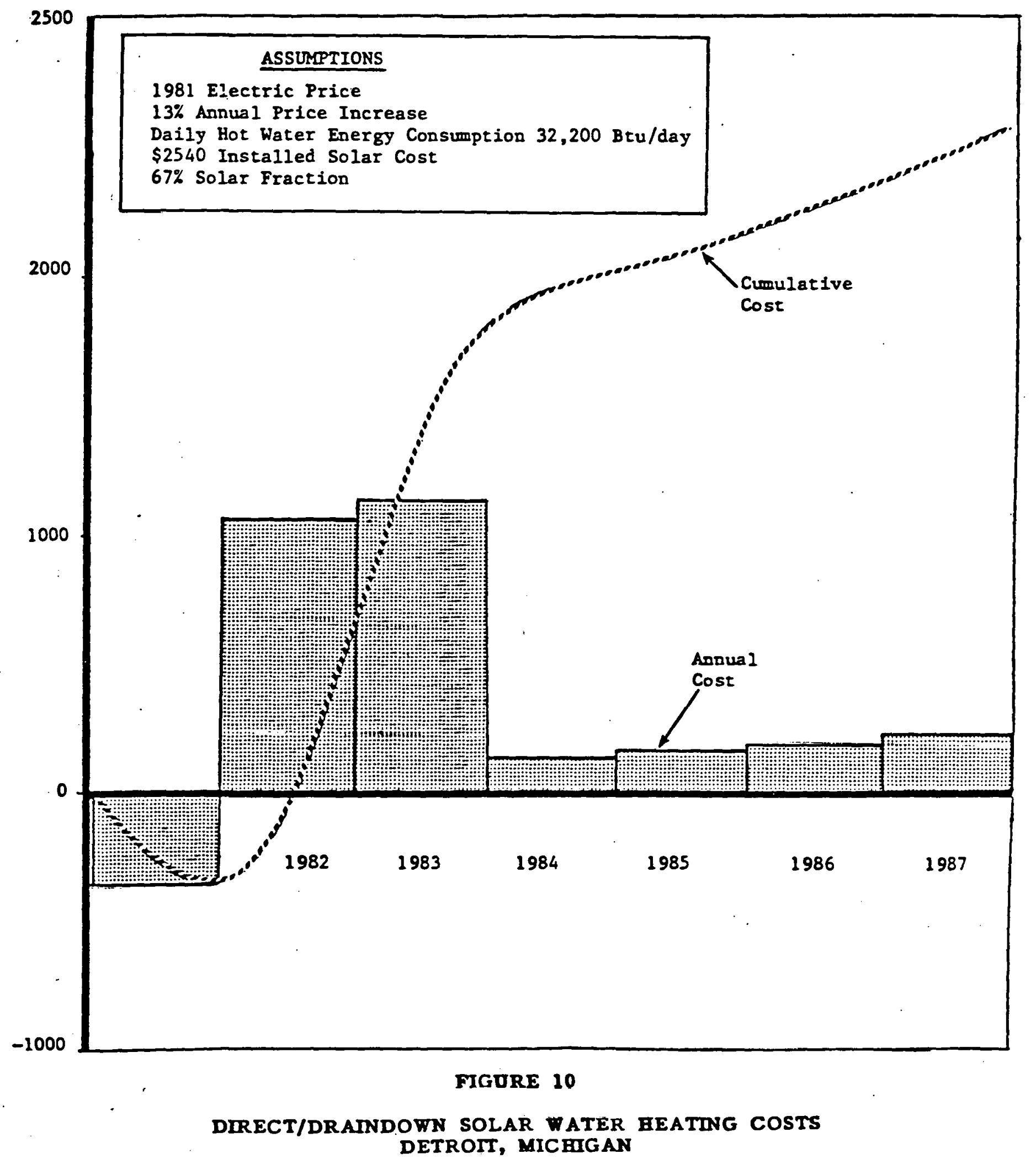




\section{THIS PAGE WAS INTENTIONALLY LEFT BLANK}




\section{REFERENCES}

1. "A Comparison of Six Generic Solar Domestic Hot Water Systems," R.B. Farrington, L.M. Murphy and D.L. Noreen. Solar Energy Research Institute, Golden, Colorado, April 1980.

2. "Analysis of Solar Domestic Hot Water Heaters," W.E. Buckles and S.A. Klein. Solar Energy, Vol. 25, pp. 417-424, Pergamon Press, Ltd., 1980.

3. "Assessment of Solar Water Heating Industry," R. LeChevlier. Science Applications, Incorporated, Golden, Colorado, April 29, 1980.

4. "Assessment of the Potential for Heat Recovery and Load Leveling on Refrigeration Systems," Volumes 1 and 2 prepared by Arthur D. Little, Incorporated, Cambridge, Massachusetts; Planning Research Corporation/Systems Services Company, Cocoa Beach, Florida and Applied Energy Systems, Incorporated, Cape Canaveral, Florida. Prepared for Electric Power Research Institute, Palo Alto, California, March 1980.

5. "DOE Fosters Energy-Efficient Products," EPRI Journal, November 1980.

6. "Energy and the Laundry Process," W.P. Levins. ORNL/CON-41, Oak Ridge National Laboratory, Oak Ridge, Tennessee, April 1980.

7. "Energy Efficient Residence: Research Results," Office of Policy Development and Research, U.S. Department of Housing and Urban Development, 1981.

8. "FCHART (4.0) Users Manual: A Design Program for Solar Heating Systems," EES Report 50, University of Wisconsin, Engineering Experiment Station, September 1980.

9. "Fedders Heat Pump Water Heater," Fedders Sales Company, Edison, New Jersey.

10. "Heat Pump Water Heater Field Test Interim Report," Tennessee Valley Authority, Chat tanooga, Tennessee, Summar 1980.

11. "Hot Water From The Sun: A Consumer Guide to Solar Water Heating," U.S. Department of Housing and Urban Development, Washington, D.C. 1979.

12. "Programmatic and Financial Solar Incentives," John Lupoli. MASEC-R-001/R3, Mid-American Solar Energy Center, Minneapolis, Minnesota, August 1980.

13. "Research and Development of a Heat-Pump Water Heater, Volume 1 and 2," Energy Utilization Systems, Incorporated, Pittsburgh, Pennsylvania, August 1978.

15. "Solar Water Heaters: What They Can Cost, What They Can Save," Consumer Reports, May 1980, pp. 322-327.

16. SOLCOST Data Base, The University of Alabama in Huntsville, Huntsville, Alabama, May-June 1980. 
17. "TEMCOR: Heat Pump Water Heater," Energy Utilization Systems, Incorporated, Pittsburgh, Pennsylvania.

18. "TERA Base Case Analysis," American Gas Association, Arlington, Virginia, November 21, 1980.

19. "Test Procedures for Water Heaters," Federal Register, Vol. 42, No. 192, pp. 54100-54119, October 4, 1977. (Amended in Federal Registers Vol. 43, No. 203, October 17, 1978 and Vol. 44, No. 175, September 1979.)

20. "The Micro Load," J. Carter and R.G. Flower. Solar Age, September 1980, pp. 22-30.

21. "The Oregon Water Heater: A Heat Pump System for Your Hot Water Needs!" The Oregon Water Heater Company, Incorporated, Progress, Oregon, 1981. 
APPENDIX A

A-1 
FCHART PARAMETERS FOR DIRECT/DRAINDOWN SOLAR WATER HEATER

EXAMPLE FOR DETROIT, MI

COLLECTOR PARAMETERS

C1. COLLECTOR AREA

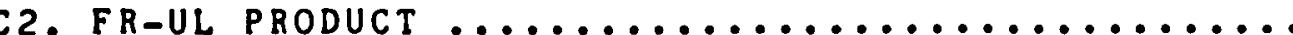

C3. FR-TAU-ALPHA (NORMAL INCIDENCE)

C6. NUMBER OF COVERS

CB. EXTINTION

C9. INCIDENCE ANGLE MODIFIER CONSTANT ...........

C10. COLLECTOR FLOW RATE SPECIFIC HEAT/AREA ......

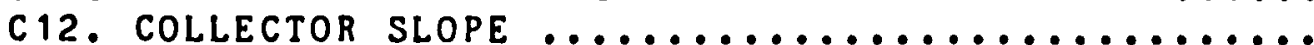

C13. COLLECTOR AZIMUTH

C14. GROUND REFLECTANCE

$\stackrel{p}{i}$

\section{COLLECTOR-STORE TRANSFER PARAMETERS}

T2. UA OF COLLECTOR INLET PIPE OR DUCT ...........

T3. UA OF COLLECTOR OUTLET PIPE OR DUCT ...........

\section{STORAGE UNIT PARAMETERS}

S1. TANK CAPACITY/COLLECTOR AREA .............. S2. STORAGE UNIT HEIGHT/DIAMETER RATIO ............

S3. HEAT LOSS COEFFICIENT .................. S4. ENVIRONMENT TEMPERATURE ( 1000 FOR TENV =TAMB) $\cdots$

S5. HOT WATER AUXILIARY TANK UA .............. S6. HOT WATER AUX TANK ENVIRONMENT TEMPERATURE .....

\section{LOAD PARAMETERS}

L3. HOT WATER USE

L4. HOT WATER SET TEMPERATURE ...............

L5. WATER MAINS TEMPERATURE

AUXILIARY PARAMETERS

A3. HOT WATER AUXILIARY FUEL $(1=G A S, 2=E L E C, 3=0 I L)$.. A 4. AUXILIARY WATER HEATER EFFICIENCY ...........

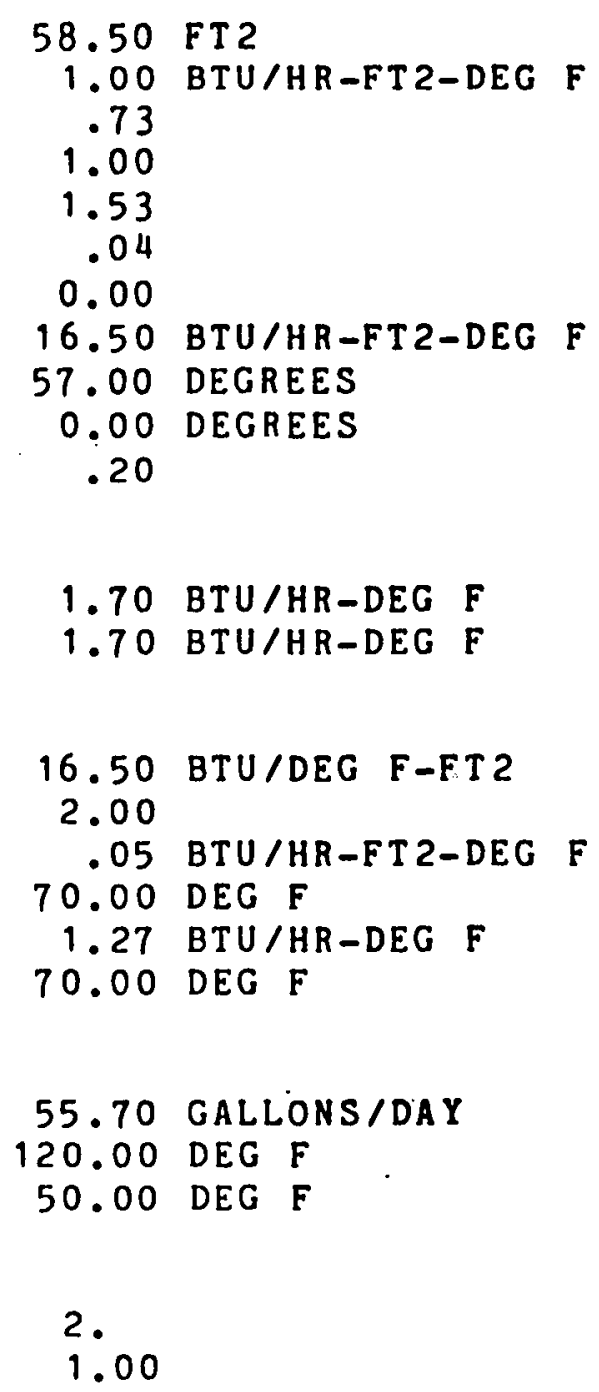

2.

1.00 


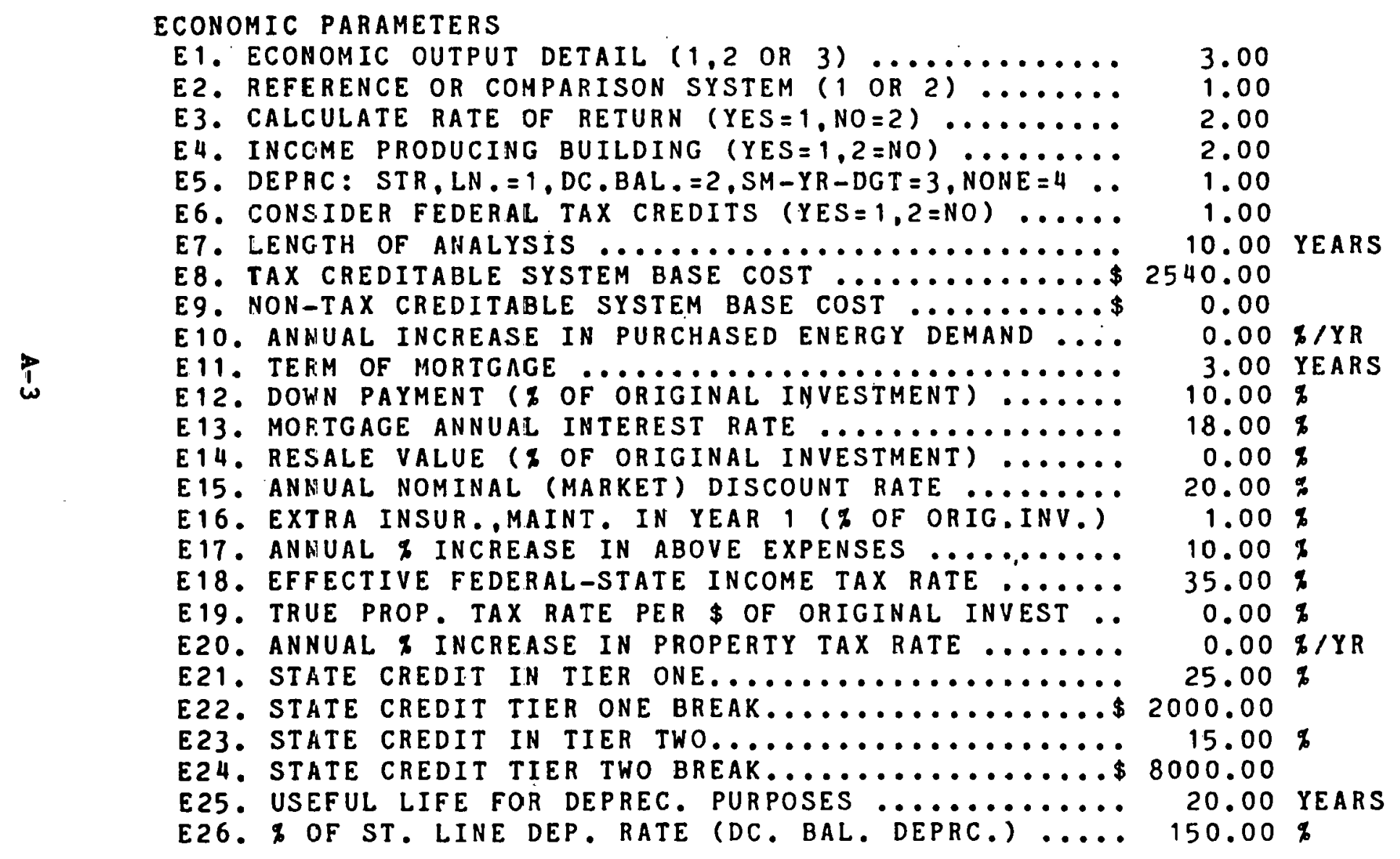




\section{DIRECT/DRAINDOWN SOLAR WATER HEATER IN CHICAGO}

CHICAGO

IL LATITUDE 41.5

THERMAL PERFORMANCE

\begin{tabular}{|c|c|c|c|c|c|c|c|}
\hline \multirow{13}{*}{$\begin{array}{c}p \\
1 \\
c\end{array}$} & & $\begin{array}{c}\text { HT } \\
\text { (MMBT }\end{array}$ & $\begin{array}{c}\text { TA } \\
(\mathrm{DEG}-1\end{array}$ & $\begin{array}{l}\text { HWLOAD } \\
\text { (MMBTU) }\end{array}$ & $\begin{array}{c}\text { QU } \\
\text { (MMBTU }\end{array}$ & $\begin{array}{l}\text { QLOSS } \\
\text { (MMBTU) }\end{array}$ & FDHW \\
\hline & JAN & 1.66 & 26.6 & 1.06 & .52 & .02 & .47 \\
\hline & FEB & 1.81 & 28.4 & .95 & .51 & .02 & .50 \\
\hline & MAR & 2.33 & 37.4 & 1.06 & .65 & .03 & .58 \\
\hline & A P R & 2.42 & 50.0 & 1.02 & .72 & .04 & .66 \\
\hline & MAY & $\begin{array}{l}2.66 \\
270\end{array}$ & 60.8 & 1.06 & .82 & .05 & .73 \\
\hline & JUL & $\begin{array}{l}2.79 \\
2.78\end{array}$ & $\begin{array}{l}69.8 \\
75.2\end{array}$ & $\begin{array}{l}1.02 \\
1.06\end{array}$ & $\begin{array}{l}.91 \\
.96\end{array}$ & $\begin{array}{l}.05 \\
.06\end{array}$ & $\begin{array}{l}.83 \\
.86\end{array}$ \\
\hline & $A \cup G$ & 2.78 & 73.4 & 1.06 & .98 & .06 & .87 \\
\hline & SEP & 2.55 & 66.2 & 1.02 & .89 & .05 & .83 \\
\hline & OCT & 2.43 & 55.4 & 1.06 & .83 & .05 & .75 \\
\hline & NOV & 1.68 & 41.0 & 1.02 & .58 & .03 & .56 \\
\hline & DEC & 1.36 & 30.2 & 1.06 & .52 & .02 & .46 \\
\hline & Y R & 27.25 & 51.2 & 12.43 & 8.89 & .47 & .68 \\
\hline & & & HA & ENERGY & SUMMARY & & \\
\hline
\end{tabular}

$\begin{array}{llclr} & \text { GAS } & \text { ELECTRIC } & \text { OIL } & \text { TOTAL } \\ \text { USE (MMBTU) } & 0.00 & 4.01 & 0.00 & 4.01 \\ \operatorname{COST~(\$ )~} & 0.00 & 77.05 & 0.00 & 77.05\end{array}$


DIRECT/DRAINDOWN SOLAR WATER HEATER IN CHICAGO

LIFE CYCLE COST ANALYSIS OF CURRENT SYSTEM

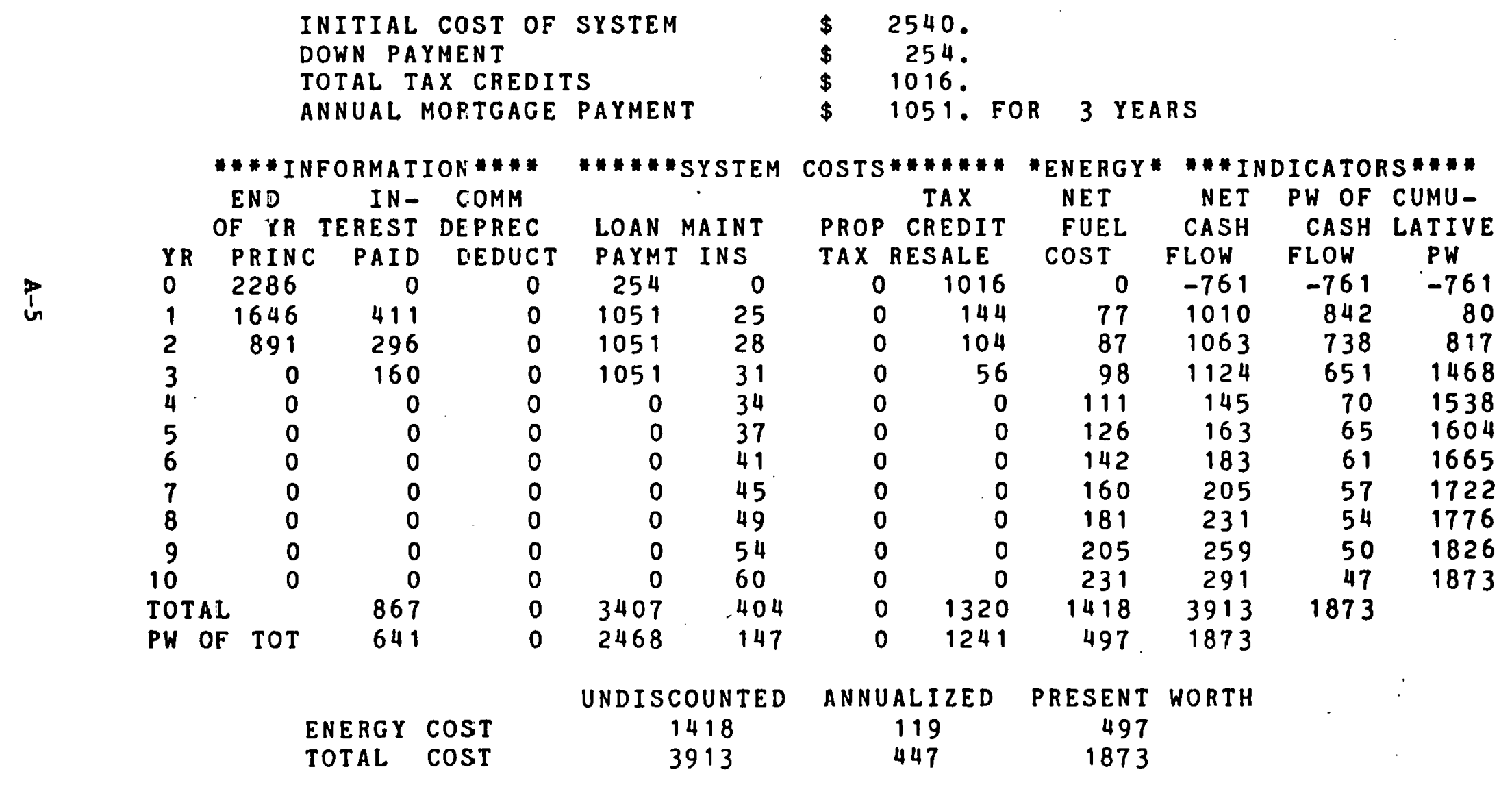


DIRECT/DRAINDOWN SOLAR WATER HEATER IN DETROIT

DETROIT

MI LATITUDE 42.3

THERMAL PERFORMANCE

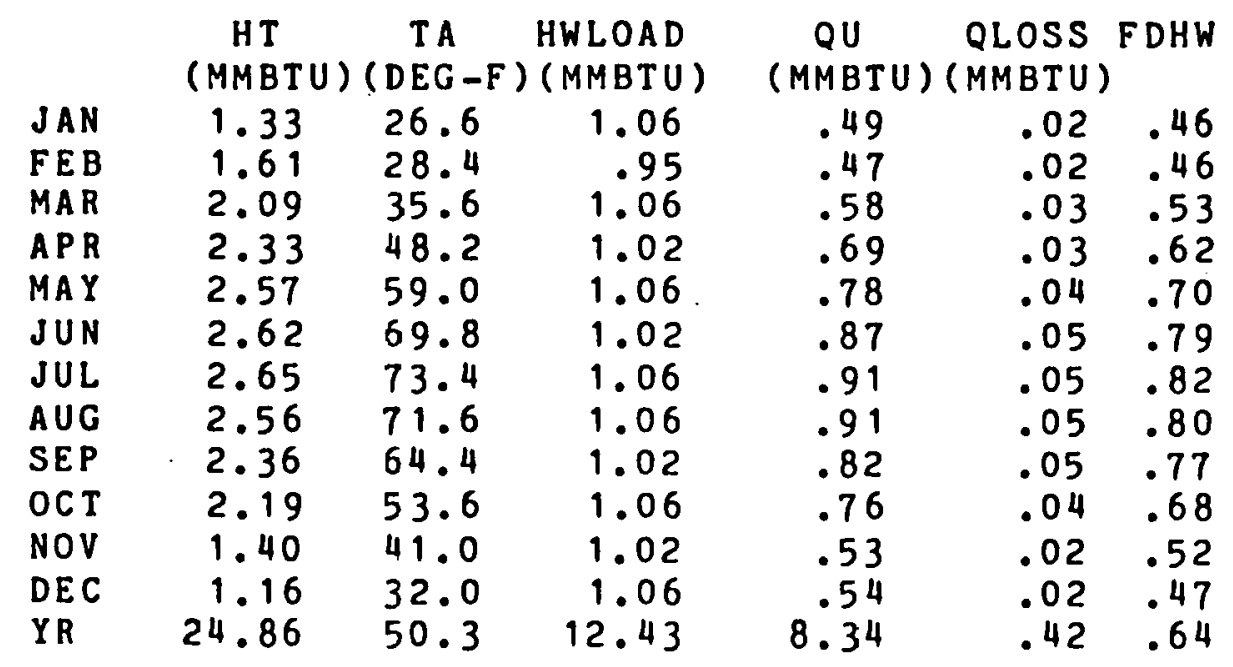

PURCHASED ENERGY SUMMARY

$\begin{array}{llclr} & \text { GAS } & \text { ELECTRIC } & \text { OIL } & \text { TOTAL } \\ \text { USE (MMBTU) } & 0.00 & 4.52 & 0.00 & 4.52 \\ \operatorname{COST}(\$) & 0.00 & 79.95 & 0.00 & 79.95\end{array}$




\section{DIRECT/DRAINDOWN SOLAR WATER HEATER IN DETROIT}

\section{LIFE CYCLE COST ANALYSIS OF CURRENT SYSTEM}

INITIAL COST OF SYSTEM DOWN PAYMENT

TOTAL TAX CREDITS

ANNUAL MORTGAGE PAYMENT

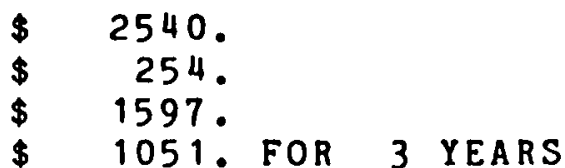

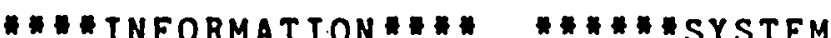
END IN - COMM OF YR TEREST DEPREC

YR FRINC PAID DEDUCT

LOAN MAINT

PAYMT INS

$\begin{array}{rr}254 & 0 \\ 1051 & 25\end{array}$

1051

1051

31

0 34

$0 \quad 37$

$\begin{array}{ll}0 & 41 \\ 0 & 45\end{array}$

0

0

0

0
3407

2468

UNDISCOUNTED

1471

3386

COS

\begin{tabular}{|c|c|c|c|c|c|}
\hline & . & 10 & & & \\
\hline $\begin{array}{l}\text { PROP } \\
\text { TAX }\end{array}$ & $\begin{array}{c}\text { TAX } \\
\text { CREDIT } \\
\text { RESALE }\end{array}$ & $\begin{array}{c}\text { NET } \\
\text { FUEL } \\
\text { COST }\end{array}$ & $\begin{array}{r}\text { NET } \\
\text { CASH } \\
\text { FLOW }\end{array}$ & $\begin{array}{l}\text { PW OF } \\
\text { CASH } \\
\text { FLOH }\end{array}$ & $\begin{array}{l}\text { CUMU- } \\
\text { LATIVE } \\
\text { PW }\end{array}$ \\
\hline 0 & 1597 & 0 & -1342 & -1342 & -1342 \\
\hline 0 & 144 & 80 & 1013 & 844 & -498 \\
\hline 0 & 104 & 90 & 1066 & 740 & 241 \\
\hline 0 & 56 & 102 & 1128 & 653 & 894 \\
\hline 0 & 0 & 115 & 149 & 72 & 966 \\
\hline 0 & 0 & 130 & 168 & 67 & 1033 \\
\hline 0 & 0 & 147 & 188 & 63 & 1096 \\
\hline 0 & 0 & 166 & 211 & 59 & 1155 \\
\hline 0 & 0 & 188 & 238 & & \\
\hline 0 & 0 & 213 & 267 & 52 & 1262 \\
\hline 0 & 0 & 240 & 300 & 48 & 1311 \\
\hline 0 & 1901 & 1471 & 338 & 1311 & \\
\hline 0 & 1822 & 515 & 1311 & & \\
\hline
\end{tabular}

ENERGY COST TOTAL COST

\section{ANNUALIZED \\ 123}

313
PRESENT WORTH

515

1311 
DIRECT/DRAINDOWN SOLAR WATER HEATER IN KANSAS CITY

KANSAS CITY MO LATITUDE 39.2

THERMAL PERFORMANCE

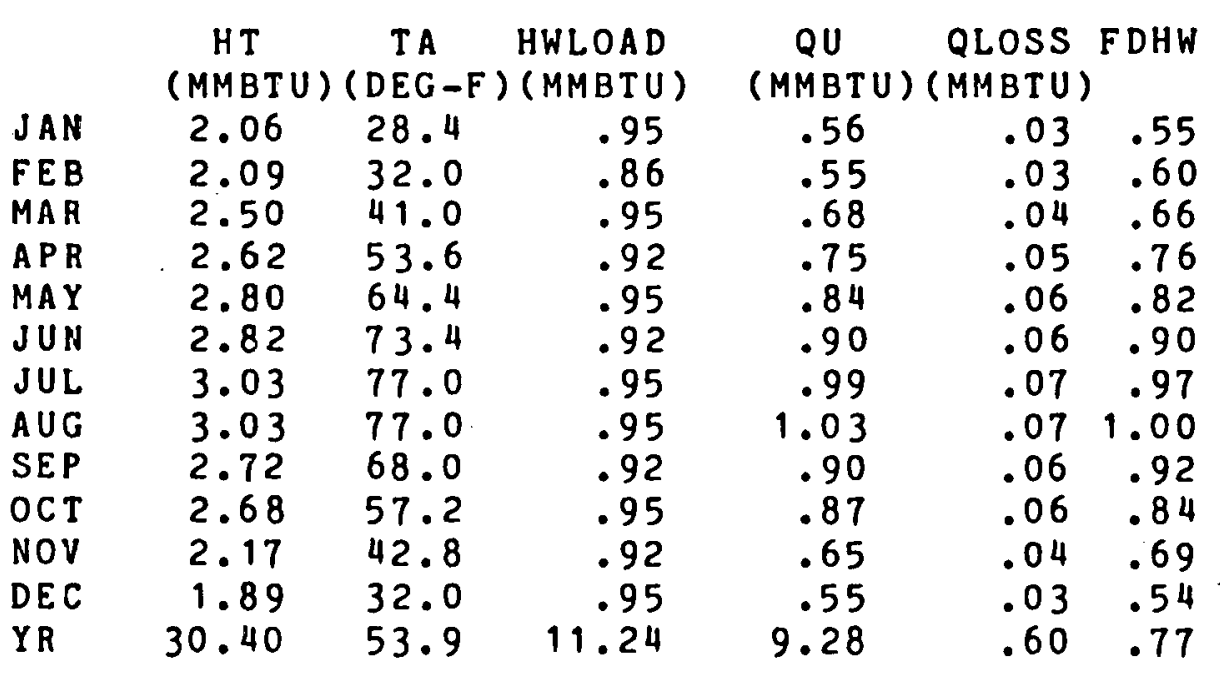

PURCHASED ENERGY SUMMARY

$\begin{array}{llclr} & \text { GAS } & \text { ELECTRIC } & \text { OIL } & \text { TOTAL } \\ \text { USE (MMBTU) } & 0.00 & 2.56 & 0.00 & 2.56 \\ \operatorname{COST}(\$) & 0.00 & 41.52 & 0.00 & 41.52\end{array}$




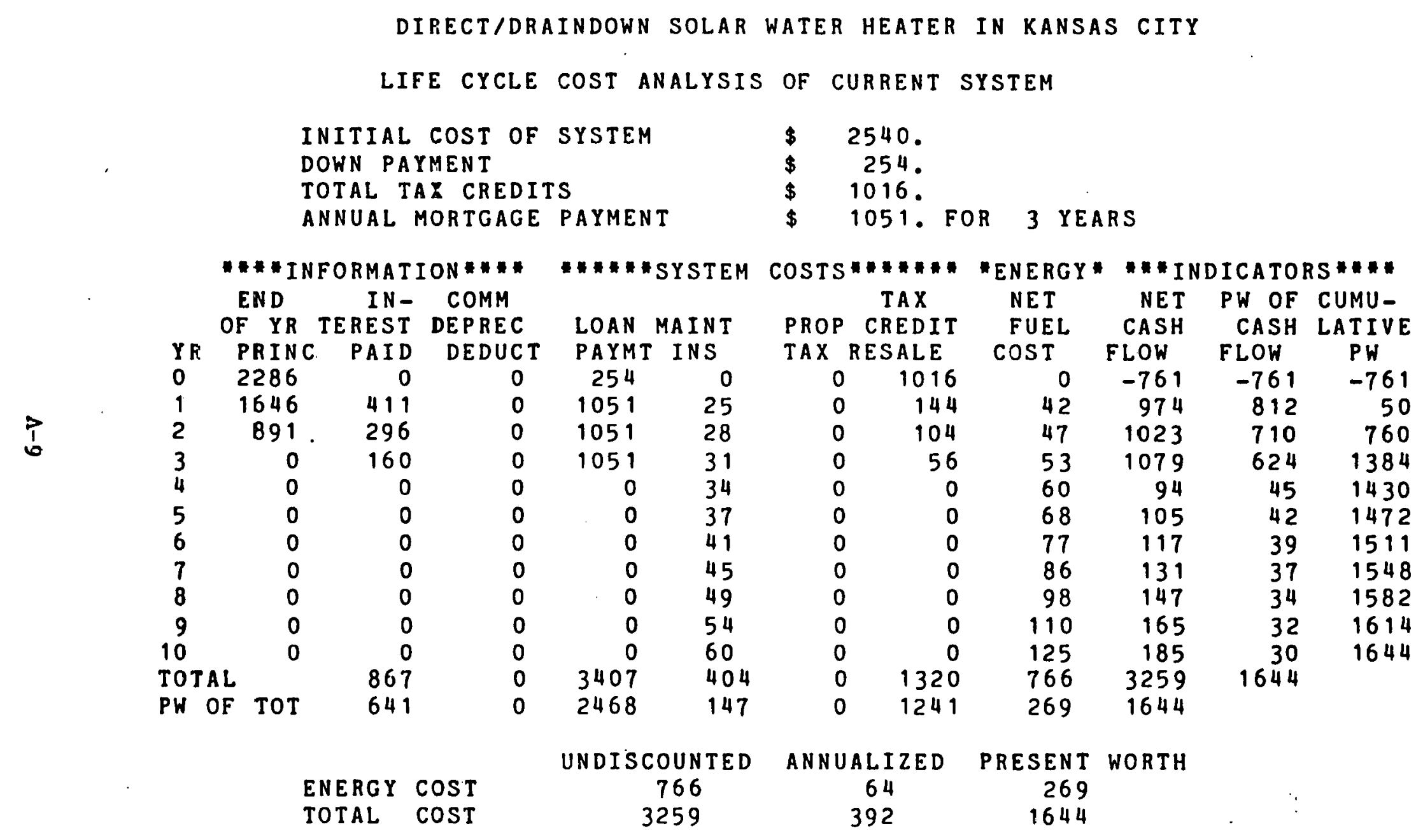


DIRECT/DRAINDOWN SOLAR WATER HEATER IN MINNEAPOLIS

\begin{tabular}{|c|c|c|c|c|c|c|}
\hline MINNEAPOLIS & $M N$ & LATII & UDE 44.5 & & & \\
\hline & & THERN & AL PERFO & MANCE & & \\
\hline & $\begin{array}{c}H T \\
\text { (MMBT }\end{array}$ & $\begin{array}{c}T A \\
(D E G-F\end{array}$ & $\begin{array}{l}\text { HWLOAD } \\
\text { (MMBTU) }\end{array}$ & $\begin{array}{c}Q U \\
\text { (MMBTU) }\end{array}$ & $\begin{array}{l}\text { QLOSS } \\
\text { (MMBTU) }\end{array}$ & FDHW \\
\hline JAN & 1.71 & 14.0 & 1.17 & .51 & .01 & .41 \\
\hline FEB & 2.00 & 17.6 & 1.06 & .53 & .01 & .49 \\
\hline MAR & 2.44 & 3.2 & 1.17 & .68 & .02 & .55 \\
\hline APR & 2.44 & 44.6 & 1.13 & .73 & .03 & .62 \\
\hline MAY & 2.60 & 57.2 & 1.17 & .84 & .04 & .68 \\
\hline JUN & 2.71 & 66.2 & 1.13 & .91 & .04 & .76 \\
\hline JUL & 2.94 & 71.6 & 1.17 & 1.04 & .05 & .83 \\
\hline$A \cup G$ & 2.77 & 69.8 & 1.17 & 1.00 & .05 & .82 \\
\hline SEP & 2.43 & 60.8 & 1.13 & .87 & .04 & .74 \\
\hline OCT & 2.26 & 50.0 & 1.17 & .80 & .03 & .66 \\
\hline NOV & 1.55 & 32.0 & 1.13 & .55 & .02 & .49 \\
\hline DEC & 1.36 & 21.2 & 1.17 & .52 & .01 & .43 \\
\hline YR & 27.19 & 44.6 & 13.78 & 8.98 & .36 & .62 \\
\hline & & HAS & ENERGY & SUMMARY & & \\
\hline
\end{tabular}

$\begin{array}{llclr} & \text { GAS } & \text { ELECTRIC } & \text { OIL } & \text { TOTAL } \\ \text { USE (MMBTU) } & 0.00 & 5.18 & 0.00 & 5.18 \\ \operatorname{COST~(\$ )~} & 0.00 & 76.64 & 0.00 & 76.64\end{array}$


DIRECT/DRAINDOWN SOLAR WATER HEATER IN MINNEAPOLIS

LIFE CYCLE COST ANALYSIS OF CURRENT SYSTEM

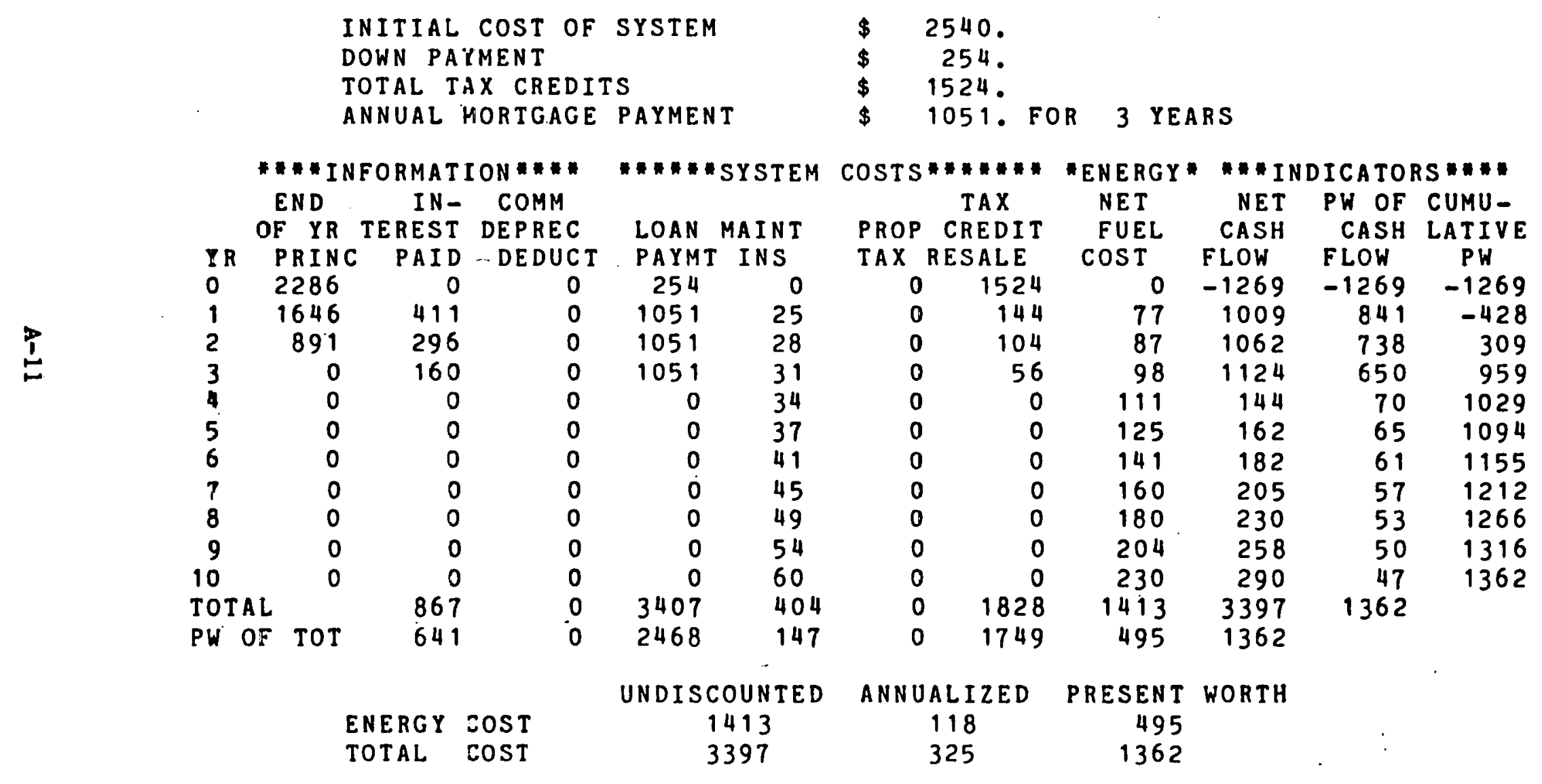


DIRECT/DRAINDOWN SOLAR WATER HEATER IN RAPID CITY

RAPID CITY

SD LATITUDE 44.0

THERMAL PERFORMANCE

$\begin{array}{lcccccc} & \text { HT } & \text { TA } & \text { HWLOAD } & \text { QU } & \text { QLOSS } & \text { FDHW } \\ \text { JAN } & \text { (MMBTU) } & (\text { DEG }-F) & \text { (MMBTU) } & \text { (MMBTU) } & (\text { MMBTU) } & \\ \text { FEB } & 2.04 & 23.0 & 1.10 & .58 & .02 & .52 \\ \text { MAR } & 2.17 & 28.4 & .99 & .62 & .03 & .58 \\ \text { APR } & 2.74 & 32.0 & 1.10 & .74 & .04 & .64 \\ \text { MAY } & 2.70 & 44.6 & 1.06 & .77 & .04 & .68 \\ \text { JUN } & 2.81 & 55.4 & 1.10 & .84 & .04 & .72 \\ \text { JUL } & 2.97 & 64.4 & 1.06 & .93 & .05 & .82 \\ \text { AUG } & 3.17 & 73.4 & 1.10 & 1.08 & .06 & .92 \\ \text { SEP } & 3.23 & 71.6 & 1.10 & 1.11 & .07 & .95 \\ \text { OCT } & 2.00 & 60.8 & 1.06 & 1.00 & .06 & .89 \\ \text { NOV } & 2.23 & 50.0 & 1.10 & .95 & .05 & .82 \\ \text { DEC } & 1.95 & 35.6 & 1.06 & .69 & .03 & .64 \\ \text { YR } & 31.93 & 47.4 & 1.10 & .61 & .02 & .53 \\ & & & 12.94 & 9.92 & .51 & .73\end{array}$

PURCHASED ENERGY SUMMARY

$\begin{array}{llclr} & \text { GAS } & \text { ELECTRIC } & \text { OIL } & \text { TOTAL } \\ \text { USE (MMBTU) } & 0.00 & 3.53 & 0.00 & 3.53 \\ \operatorname{COST}(\$) & 0.00 & 45.93 & 0.00 & 45.93\end{array}$




\section{DIRECT/DRAINDOWN SOLAR WATER HEATER IN RAPID CITY}

\section{LIFE CYCLE COST ANALYSIS OF CURRENT SYSTEM}

INITIAL COST OF SYSTEM DOWN PAYHENT TOTAL TAX CREDITS

ANNUAL MORTGAGE PAYMENT

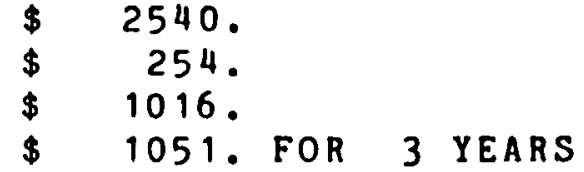

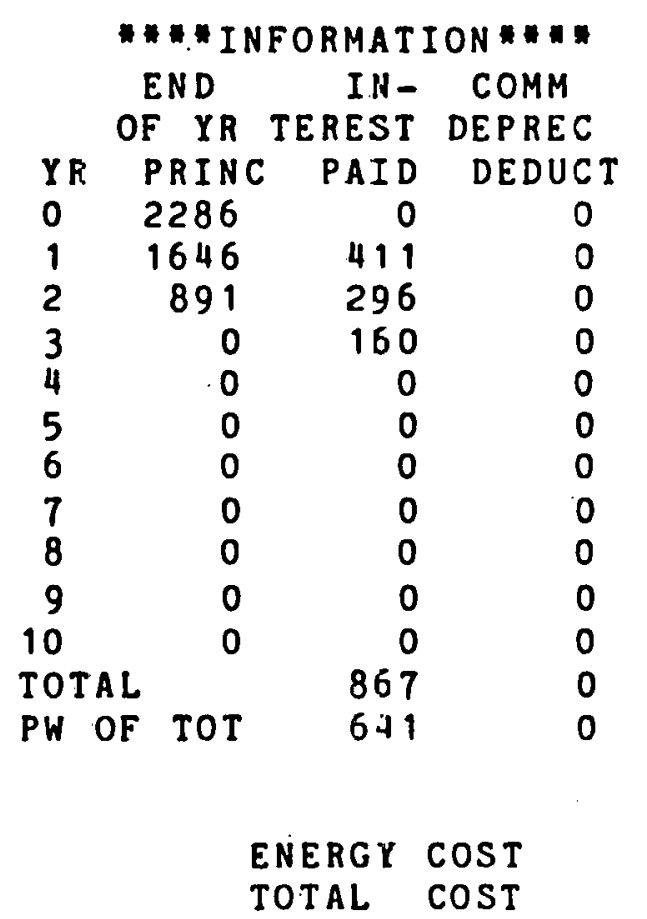

** * SYSTEM

LOAN MAINT

PAYMT INS

$\begin{array}{rr}254 & 0 \\ 1051 & 25\end{array}$

$1051 \quad 28$

$1051 \quad 31$

$0 \quad 34$

$0 \quad 37$

041

045

$0 \quad 49$

$0 \quad 54$

$\begin{array}{rl}0 & 60 \\ 3407 & 404\end{array}$

2468

147

UNDISCOUNTED

847

3343
*ENERGY *

"INDICATORS " *

NET PW OF CUMU-

FUEL CASH CASH LATIVE

TAX RESALE COST FLOW FLOW PW

$\begin{array}{llllll}0 & 1016 & 0 & -761 & -761 & -761\end{array}$

$\begin{array}{llllll}0 & 144 & 46 & 979 & 816 & 54\end{array}$

$\begin{array}{llllll}0 & 104 & 52 & 1028 & 714 & 767\end{array}$

$\begin{array}{llllll}0 & 56 & 59 & 1085 & 628 & 1395\end{array}$

$\begin{array}{llllll}0 & 0 & 66 & 100 & 48 & 1443\end{array}$

$\begin{array}{llllll}0 & 0 & 75 & 112 & 45 & 1488\end{array}$

$\begin{array}{llllll}0 & 0 & 85 & 126 & 42 & 1530\end{array}$

$\begin{array}{llllll}0 & 0 & 96 & 141 & 39 & 1569\end{array}$

$\begin{array}{llllll}0 & 0 & 108 & 158 & 37 & 1606\end{array}$

$\begin{array}{llllll}0 & 0 & 122 & 177 & 34 & 1640\end{array}$

$\begin{array}{rrrrr}0 & 138 & 198 & 32 & 1672\end{array}$

$\begin{array}{lllll}0 & 1320 & 847 & 3343 & 1672\end{array}$

ANNUALIZED PRESENT WORTH

$71 \quad 297$

$399 \quad 1672$ 
FCHART PARAMETERS FOR INDIRECT/ANTIFREEZE SOLAR WATER HEATER EXAMPLE FOR DETROIT, MI

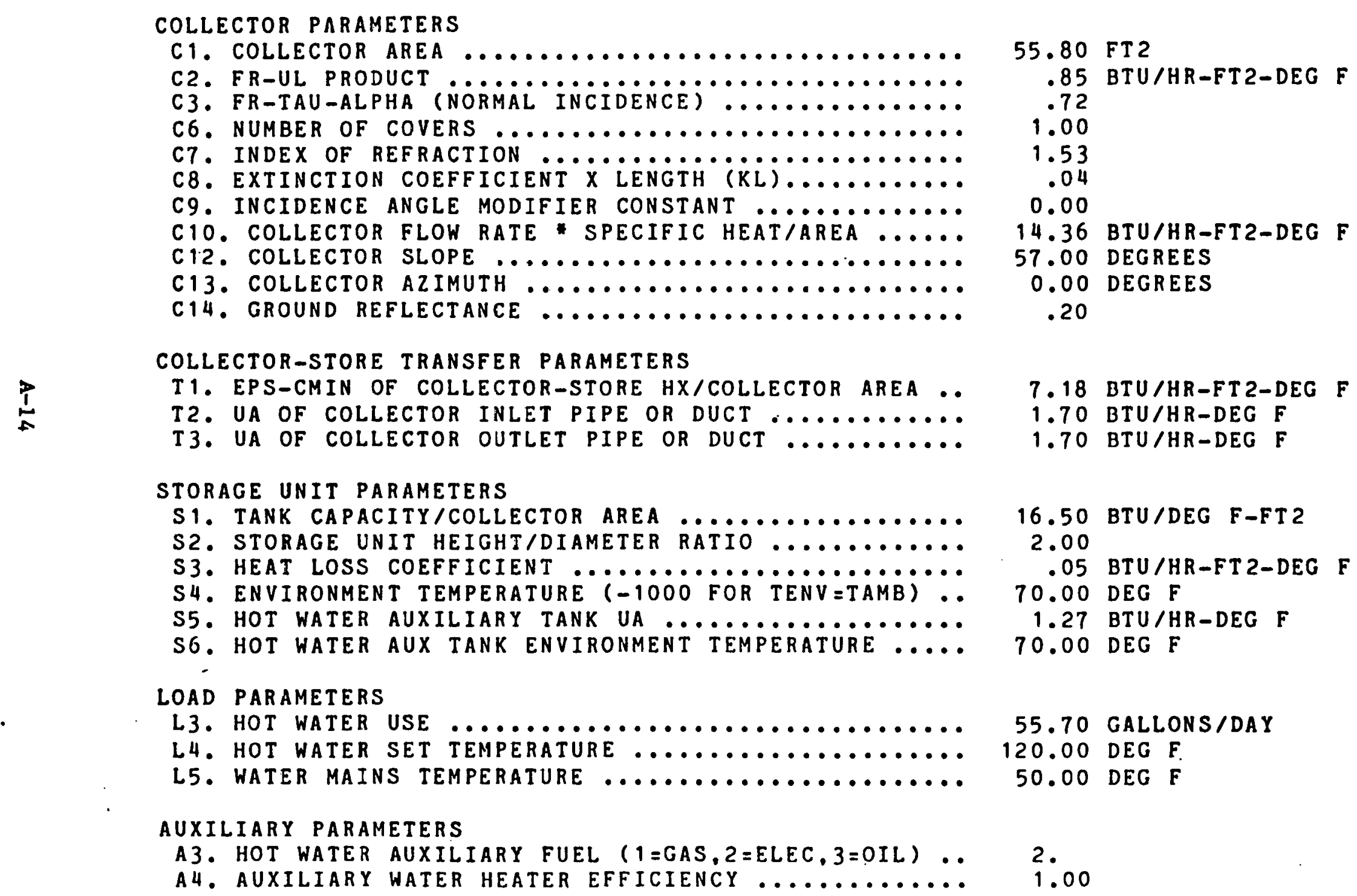




\section{FCHART PARAMETERS FOR INDIRECT/ANTIFREEZE SOLAR WATER HEATER EXAMPLE FOR DETROIT, MI}

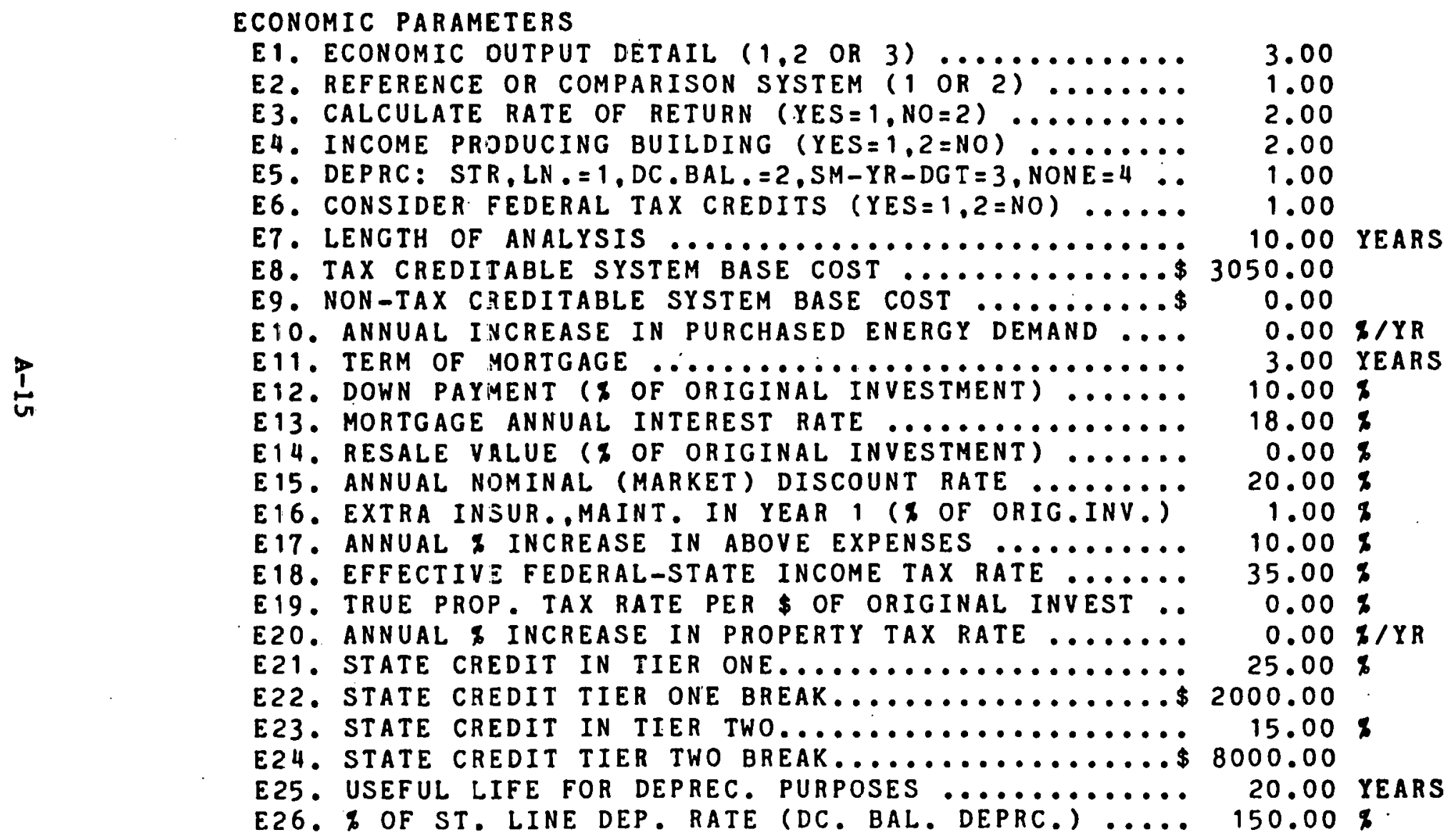


INDIRECT/ANTIFREEZE SOLAR WATER HEATER IN CHICAGO

CHICAGO

$\stackrel{p}{\stackrel{1}{a}}$
IL LATITUDE 41.5

THERMAL PERFORMANCE

$\begin{array}{lcccccc} & \text { HT } & \text { TA } & \text { HWLOAD } & \text { QU } & \text { QLOSS } & \text { FDHW } \\ \text { JAN } & \text { (MMBTU) } & (\text { DEG }-F) & (\text { MMBTU) } & \text { (MMBTU) } & \text { (MMBTU) } \\ \text { FEB } & 1.58 & 26.6 & 1.06 & .51 & .02 & .47 \\ \text { MAR } & 1.72 & 28.4 & .95 & .51 & .02 & .51 \\ \text { APR } & 2.22 & 37.4 & 1.06 & .65 & .03 & .59 \\ \text { MAY } & 2.31 & 50.0 & 1.02 & .71 & .04 & .66 \\ \text { JUN } & 2.53 & 60.8 & 1.06 & .81 & .04 & .73 \\ \text { JUL } & 2.66 & 69.8 & 1.02 & .90 & .05 & .82 \\ \text { AUG } & 2.65 & 75.2 & 1.06 & .94 & .05 & .85 \\ \text { SEP } & 2.43 & 73.4 & 1.06 & .96 & .06 & .85 \\ \text { OCT } & 2.32 & 55.4 & 1.06 & .82 & .04 & .74 \\ \text { NOV } & 1.61 & 41.0 & 1.02 & .57 & .03 & .55 \\ \text { DEC } & 1.30 & 30.2 & 1.06 & .51 & .02 & .45 \\ \text { YR } & 25.99 & 51.2 & 12.43 & 8.77 & .45 & .67\end{array}$

PURCHASED ENERGY SUMMARY

$\begin{array}{llclr} & \text { GAS } & \text { ELECTRIC } & \text { OIL } & \text { TOTAL } \\ \text { USE (MMBTU) } & 0.00 & 4.11 & 0.00 & 4.11 \\ \operatorname{COST~(\$ )~} & 0.00 & 78.86 & 0.00 & 78.86\end{array}$


INDIRECT/ANTIFREEZE SOLAR WATER HEATER IN CHICAGO

LIFE CYCLE COST ANALYSIS OF CURRENT SYSTEM

INITIAL COST OF SYSTEM DOWN PAYMENT TOTAL TAX CREDITS ANNUAL MORTGAGE PAYMENT

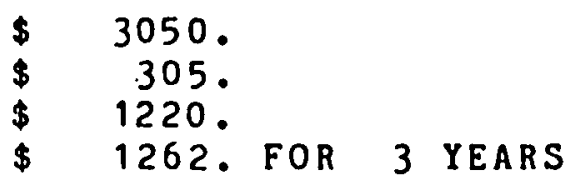

\begin{tabular}{|c|c|c|c|c|c|c|c|c|c|c|c|}
\hline & $\because *$ IN & FORMAT I & ION & 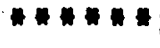 & SYSTEM & $\cos$ & 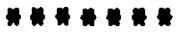 & ENERGY & & ICATO & 1. \\
\hline & EN D & IN- & COMM & & & & TAX & NET & NET & $P H \quad O F$ & CUMU - \\
\hline & OF YR & TEREST & DEPREC & LOAN & MAINT & PROP & CREDIT & FUEL & CASH & CASH & LATIVE \\
\hline YR & PRINC & PAID & DEDUCT & PAYMT & INS & TAX & RESALE & $\cos \mathrm{T}$ & FLOW & FLOW & PW \\
\hline 0 & 2745 & 0 & 0 & 305 & 0 & 0 & 1220 & 0 & -914 & -914 & -914 \\
\hline 1 & 1977 & 494 & 0 & 1262 & 30 & 0 & 173 & 79 & 1199 & 999 & 84 \\
\hline 2 & 1070 & 356 & 0 & 1262 & 34 & 0 & 125 & 89 & 1261 & 875 & 960 \\
\hline 3 & 0 & 193 & 0 & 1262 & 37 & 0 & 67 & 101 & 1333 & 771 & 1731 \\
\hline 4 & 0 & 0 & 0 & 0 & 41 & 0 & 0 & 114 & 154 & 74 & 1805 \\
\hline 5 & 0 & 0 & 0 & 0 & 45 & 0 & 0 & 129 & 173 & 70 & 1875 \\
\hline 6 & 0 & 0 & 0 & 0 & 49 & 0 & 0 & 145 & 194 & 65 & 1940 \\
\hline 7 & 0 & 0 & 0 & 0 & 54 & 0 & 0 & 164 & 218 & 61 & 2001 \\
\hline 8 & 0 & 0 & 0 & 0 & 59 & 0 & 0 & 186 & 245 & 57 & 2058 \\
\hline 9 & 0 & 0 & 0 & 0 & 65 & 0 & 0 & 210 & 275 & 53 & 2111 \\
\hline 10 & 0 & & 0 & 0 & 72 & 0 & 0 & 237 & 309 & 50 & 2161 \\
\hline TOTAL & & 1043 & 0 & 4091 & 486 & 0 & 1585 & 1454 & 4447 & 2161 & \\
\hline PW OF & F TOT & 771 & 0 & 2963 & 177 & 0 & 1490 & 509 & 2161 & & \\
\hline & & & & UNDISC & COUNTED & ANNU & ALIZED & PRESENT & WORTH & & \\
\hline & & NERGY & $\cos T$ & & 1454 & & 121 & 509 & & & \\
\hline & & OTAL & $\operatorname{cost}$ & & 4447 & & 515 & 2161 & & & \\
\hline
\end{tabular}


INDIRECT/ANTIFREEZE SOLAR WATER HEATER IN DETROIT

DETROIT

MI LATITUDE 42.3

THERMAL PERFORMANCE

\begin{tabular}{|c|c|c|c|c|c|c|}
\hline & $\begin{array}{c}H T \\
\text { (MMBT) }\end{array}$ & $\begin{array}{c}T A \\
(D E G-F\end{array}$ & $\begin{array}{l}\text { HWLOAD } \\
\text { (MMBTU) }\end{array}$ & $\begin{array}{c}\text { QU } \\
\text { (MMBTL }\end{array}$ & $\begin{array}{l}\text { QLOSS } \\
\text { (MMBTU) }\end{array}$ & FDHW \\
\hline JAN & 1.27 & 26.6 & 1.06 & .47 & .02 & .44 \\
\hline FEB & 1.54 & 28.4 & .95 & .47 & .02 & .46 \\
\hline MAR & 1.99 & 35.6 & 1.06 & .58 & .02 & .2 \\
\hline A P R & 2.22 & 48.2 & 1.02 & .68 & .03 & 62 \\
\hline MAY & 2.45 & 59.0 & 1.06 & .77 & .04 & .70 \\
\hline JUN & 2.50 & 69.8 & 1.02 & .86 & .05 & .78 \\
\hline JUL & 2.53 & 73.4 & 1.06 & .89 & .05 & .81 \\
\hline$A \cup G$ & 2.44 & 71.6 & 1.06 & .89 & .05 & .7 \\
\hline SEP & 25 & & 1.02 & & .04 & \\
\hline $\mathrm{OCT}$ & 2.09 & 53.6 & 1.06 & .74 & .04 & 67 \\
\hline NOV & 1.33 & 41.0 & 1.02 & .51 & .02 & .51 \\
\hline DEC & 1.11 & 32.0 & 1.06 & .51 & .02 & .45 \\
\hline YR & 23.72 & 50.3 & 12.43 & 8.19 & .40 & .63 \\
\hline
\end{tabular}

PURCHASED ENERGY SUMMARY

$\begin{array}{llclr} & \text { GAS } & \text { ELECTRIC } & \text { OIL } & \text { TOTAL } \\ \text { USE (MMBTU) } & 0.00 & 4.64 & 0.00 & 4.64 \\ \operatorname{COST}(\$) & 0.00 & 82.11 & 0.00 & 82.11\end{array}$


INDIRECT/ANTIFREEZE SOLAR WATER HEATER IN DETROIT LIFE CYCLE COST ANALYSIS OF CURRENT SYSTEM

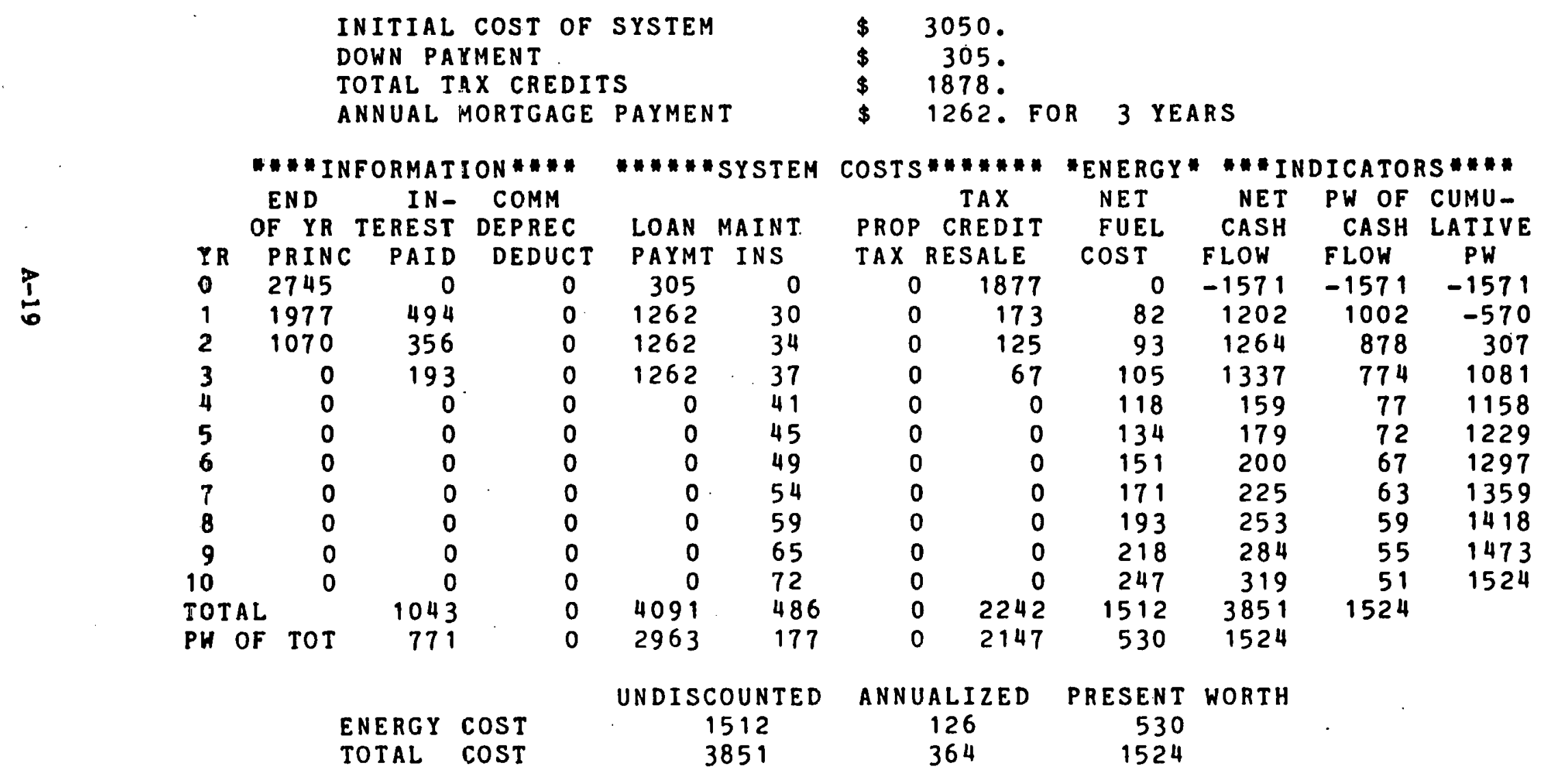


INDIRECT/ANTIFREEZE SOLAR WATER HEATER IN KANSAS CITY

KANSAS CITY MO LATITUDE 39.2

THERMAL PERFORMANCE

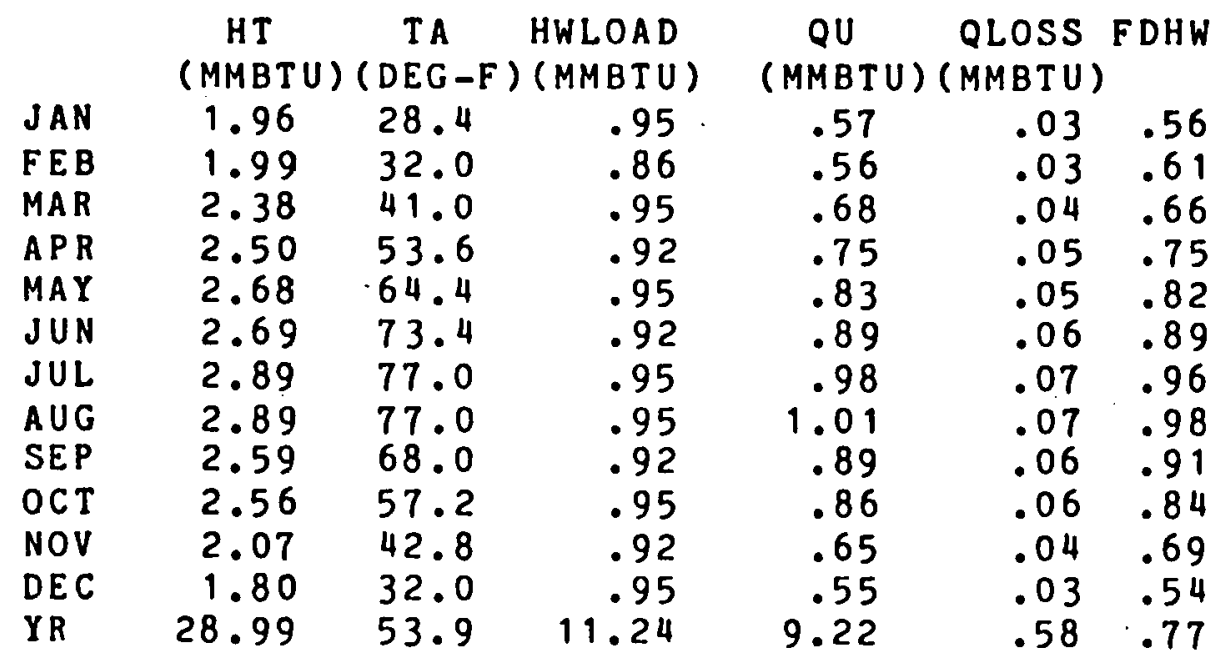

\section{PURCHASED ENERGY SUMMARY}

$\begin{array}{llclr} & \text { GAS } & \text { ELECTRIC } & \text { OIL } & \text { TOTAL } \\ \text { USE (MMBTU) } & 0.00 & 2.60 & 0.00 & 2.60 \\ \operatorname{COST~(\$ )~} & 0.00 & 42.14 & 0.00 & 42.14\end{array}$


INDIRECT/ANTIFREEZE SOLAR WATER HEATER IN KANSAS CITY LIFE CYCLE COST ANALYSIS OF CURRENT SYSTEM

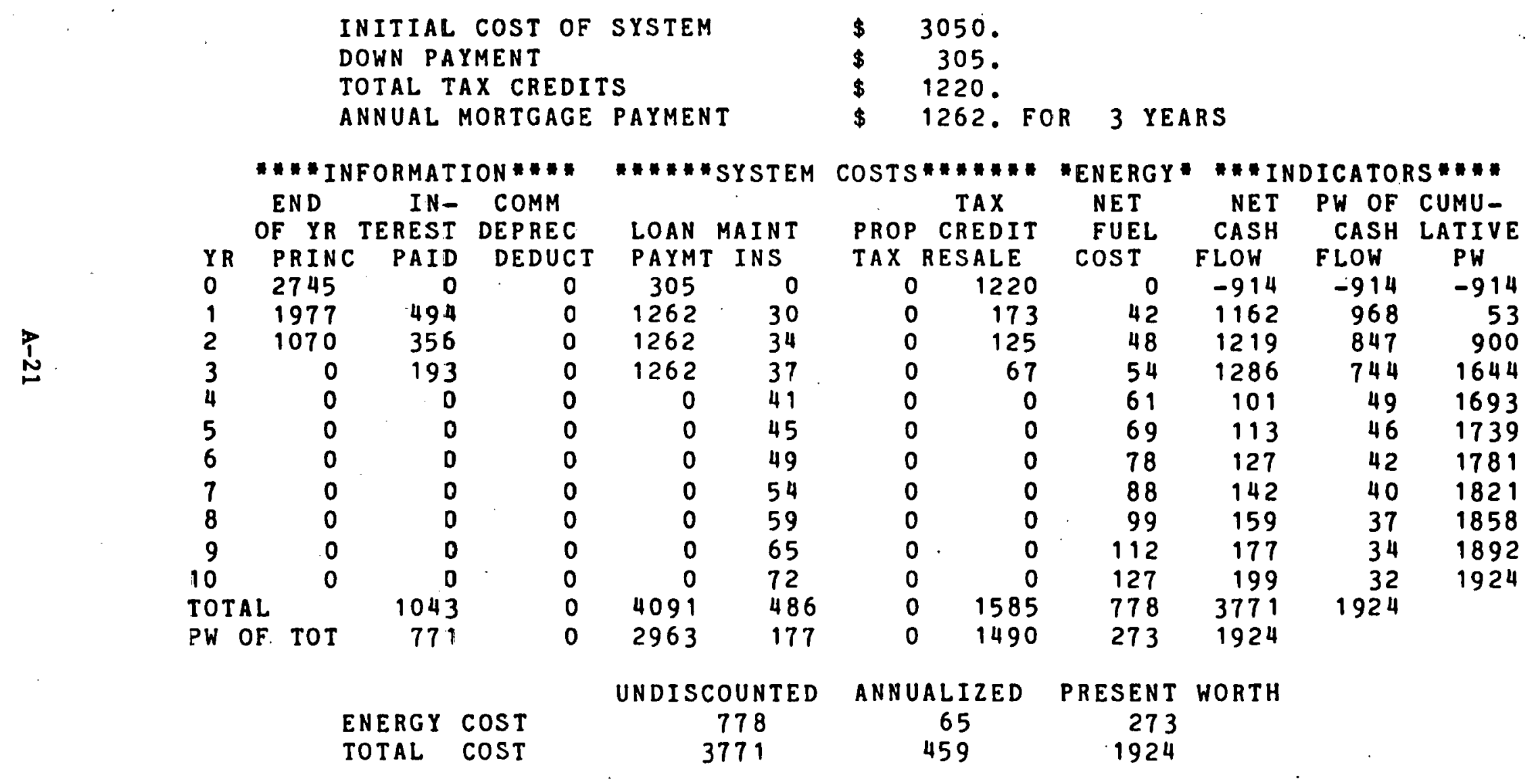


INDIRECT/ANTIFREEZE SOLAR WATER HEATER IN MINNEAPOLIS

MINNEAPOLIS MN LATITUDE 44.5

THERMAL PERFORMANCE

$\stackrel{2}{N}$

\begin{tabular}{|c|c|c|c|c|c|c|}
\hline \multirow{4}{*}{$\begin{array}{l}\text { JAN } \\
\text { FEB } \\
\text { MAR }\end{array}$} & $\begin{array}{c}\text { HT } \\
\text { (MMBTU) }\end{array}$ & $\begin{array}{c}\mathrm{TA} \\
\text { (DEG-F }\end{array}$ & $\begin{array}{l}\text { HWLOAD } \\
\text { )(MMBTU) }\end{array}$ & $\begin{array}{c}\text { QU } \\
\text { (MMBTU }\end{array}$ & $\begin{array}{l}\text { QLOSS } \\
\text { (MMBTU) }\end{array}$ & FDHW \\
\hline & 1.63 & 14.0 & 1.17 & .51 & .01 & .49 \\
\hline & 1.91 & 17.6 & 1.06 & .54 & .01 & .50 \\
\hline & 2.32 & 30.2 & 1.17 & .68 & .02 & .56 \\
\hline A P R & 2.33 & 44.6 & 1.13 & .72 & .03 & .62 \\
\hline MAY & 2.48 & 57.2 & 1.17 & .83 & .03 & .67 \\
\hline JUN & 2.58 & 66.2 & 1.13 & .90 & .04 & .75 \\
\hline JUL & 2.80 & 71.6 & 1.17 & 1.02 & .05 & .82 \\
\hline$A \cup G$ & 2.64 & 69.8 & 1.17 & .98 & .05 & .80 \\
\hline SEP & 2.31 & 60.8 & 1.13 & .86 & .04 & .72 \\
\hline OCT & 2.16 & 50.0 & 1.17 & .79 & .03 & .65 \\
\hline NOV & 1.48 & 32.0 & 1.13 & .54 & .01 & .48 \\
\hline DEC & 1.30 & 21.2 & 1.17 & .51 & .01 & .42 \\
\hline YR & 25.94 & 44.6 & 13.78 & 8.86 & .34 & .62 \\
\hline
\end{tabular}

$\begin{array}{lcccr}\text { PURCHASED ENERGY SUMMARY } \\ \text { GAS } & \text { ELECTRIC } & \text { OIL } & \text { TOTAL } \\ \text { USE (MMBTU) } & 0.00 & 5.28 & 0.00 & 5.28 \\ \operatorname{COST~(\$ )~} & 0.00 & 78.13 & 0.00 & 78.13\end{array}$




\section{INDIRECT/ANTIFREEZE SOLAR WATER HEATER IN MINNEAPOLIS}

\section{LIFE CYCLE COST ANALYSIS OF CURRENT SYSTEM}

INITIAL COST OF SYSTEM DOWN PAYMENT TOTAL TAX CREDITS

ANNUAL MORTGAGE PAYMENT

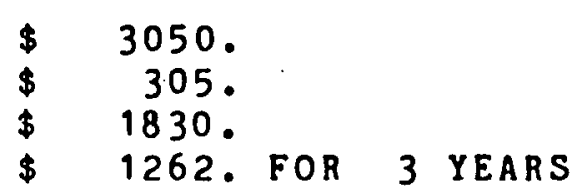

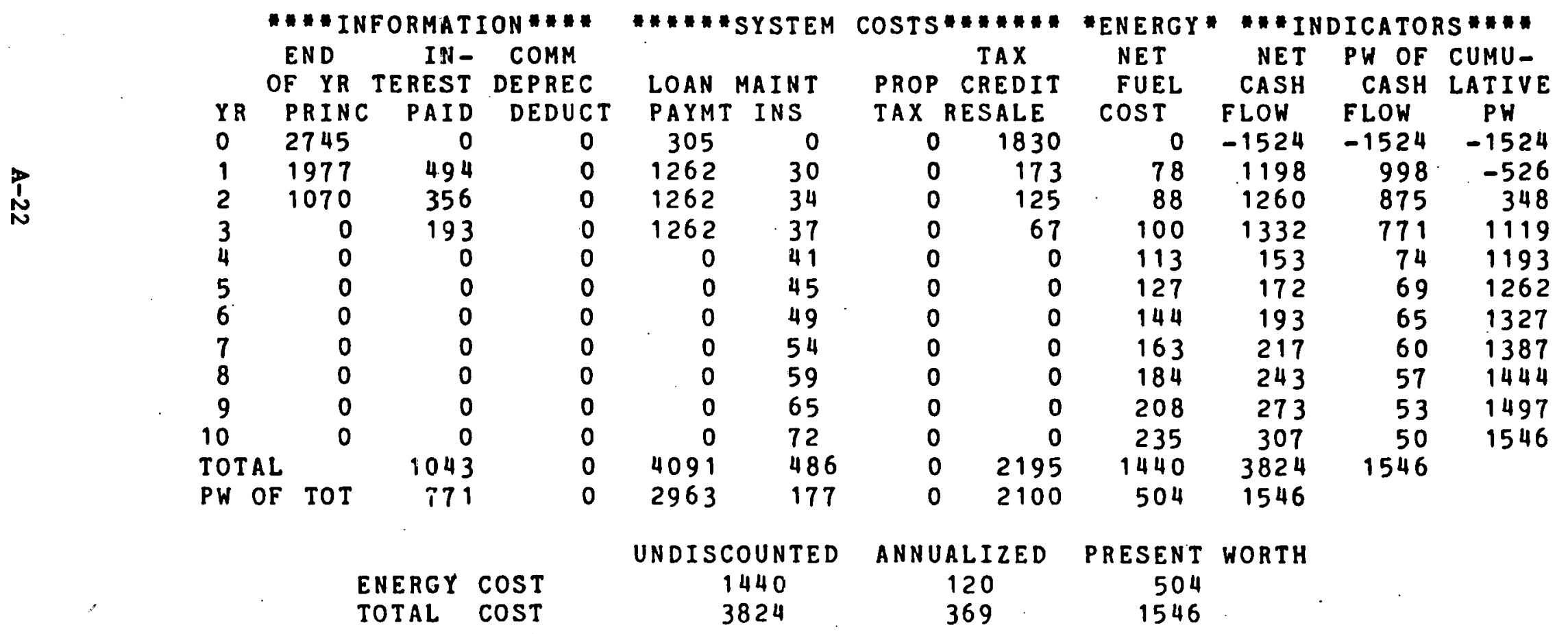


INDIRECT/ANTIFREEZE SOLAR WATER HEATER IN RAPID.CITY

RAPID CITY

SD LATITUDE 44.0

THERMAL PERFORMANCE

$\begin{array}{lcccccc} & \text { HT } & \text { TA } & \text { HWLOAD } & \text { QU } & \text { QLOSS } & \text { FDHW } \\ \text { JAN } & (\text { MMBTU) } & \text { (DEG-F) } & \text { (MMBTU) } & \text { (MMBTU) (MMBTU) } & \\ \text { FEB } & 1.94 & 23.0 & 1.10 & .59 & .02 & .52 \\ \text { MAR } & 2.07 & 28.4 & .99 & .62 & .03 & .59 \\ \text { APR } & 2.62 & 32.0 & 1.10 & .74 & .03 & .65 \\ \text { MAY } & 2.68 & 44.6 & 1.06 & .77 & .04 & .68 \\ \text { JUN } & 2.83 & 55.4 & 1.10 & .83 & .04 & .72 \\ \text { JUL } & 3.02 & 74.4 & 1.06 & .92 & .05 & .81 \\ \text { AUG } & 3.09 & 71.6 & 1.10 & 1.06 & .06 & .91 \\ \text { SEP } & 2.86 & 60.8 & 1.10 & 1.09 & .06 & .94 \\ \text { OCT } & 2.77 & 50.0 & 1.06 & .99 & .06 & .89 \\ \text { NOV } & 2.13 & 35.6 & 1.06 & .94 & .05 & .81 \\ \text { DEC } & 1.86 & 28.4 & 1.10 & .69 & .03 & .64 \\ \text { YR } & 30.46 & 47.3 & 12.94 & 9.81 & .02 & .53 \\ & & & & & .49 & .72\end{array}$

PURCHASED ENERGY SUMMARY

$\begin{array}{llclr} & \text { GAS } & \text { ELECTRIC } & \text { OIL } & \text { TOTAL } \\ \text { USE (MMBTU) } & 0.00 & 3.58 & 0.00 & 3.58 \\ \operatorname{COST~}(\$) & 0.00 & 46.53 & 0.00 & 46.53\end{array}$




\section{INDIRECT/ANTIFREEZE SOLAR WATER HEATER IN RAPID CITY}

LIFE CYCLE COST ANALYSIS OF CURRENT SYSTEM

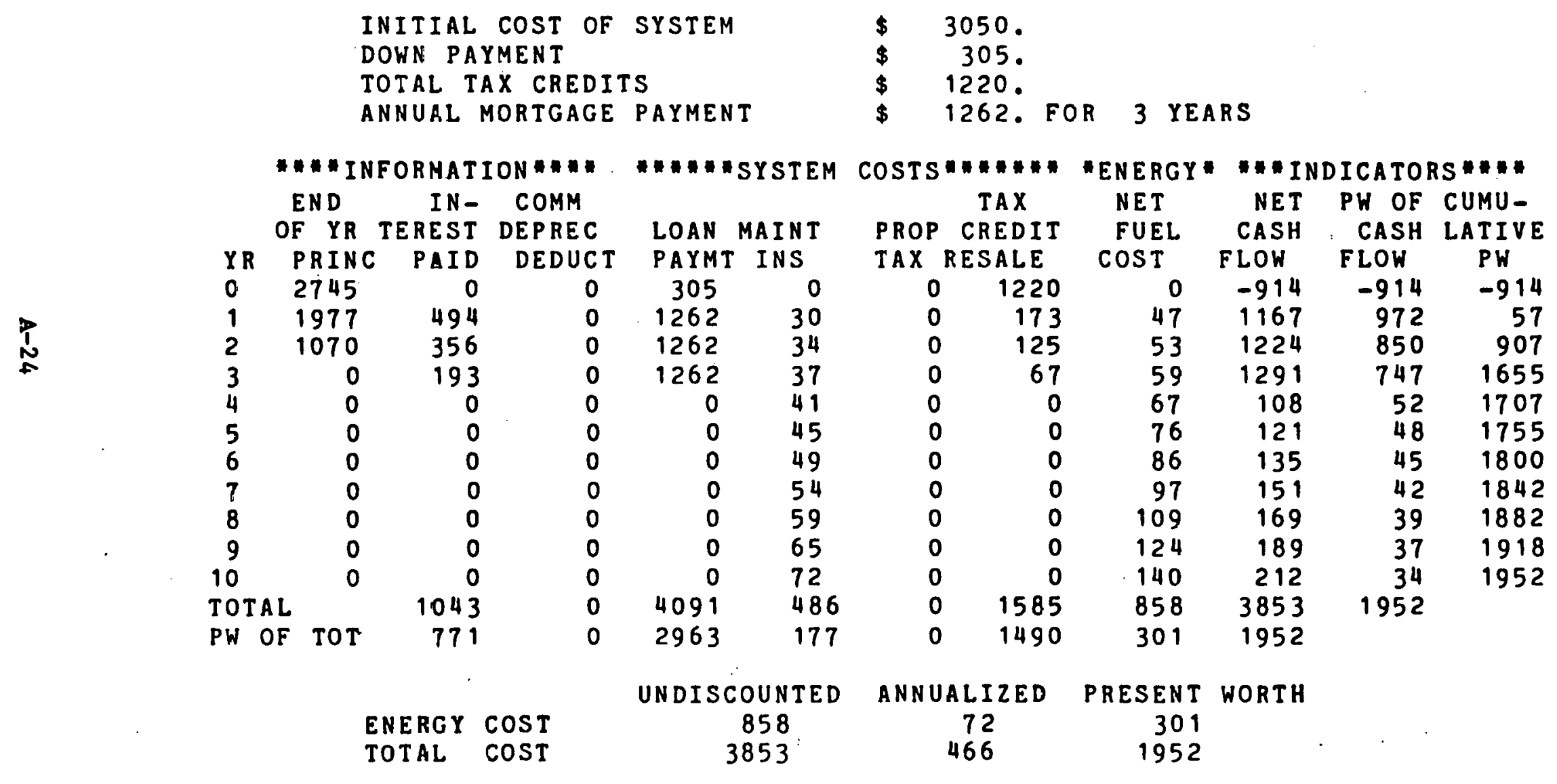

